\title{
Molecular Mechanism of Puerarin Against Diabetes and its Complications
}

\author{
Yi-ling Bai ${ }^{1}$, Ling-ling Han ${ }^{1}$, Jun-hui Qian ${ }^{2 *}$ and Hao-zhong Wang ${ }^{1 *}$ \\ ${ }^{1}$ College of Basic Medicine, Chengdu University of Traditional Chinese Medicine, Chengdu, China, ${ }^{2}$ Affiliated Hospital of Chengdu \\ University of Traditional Chinese Medicine, Chengdu, China
}

Puerarin is a predominant component of Radix Puerarin. Despite its anti-tumor and anti-virus effects and efficacy in improving cardiovascular or cerebrovascular diseases and preventing osteoporosis, it has been shown to protect against diabetes and its complications. This review summarizes the current knowledge on Puerarin in diabetes and related complications, aiming to provide an overview of antidiabetic mechanisms of Puerarin and new targets for treatment.

Keywords: diabetes, diabetes complications, puerarin, hypoglycemic mechanism, protection mechanisms

\section{OPEN ACCESS INTRODUCTION}

Edited by: Alejandro Urzua

University of Santiago, Chile

Reviewed by:

Xianju Huang,

South-Central University for Nationalities, China

Shiyu Song,

Nanjing University, China

${ }^{*}$ Correspondence: Jun-hui Qian

495535317@qq.com Hao-zhong Wang wanghaozhong@cdutcm.edu.cn

Specialty section: This article was submitted to Ethnopharmacology,

a section of the journal Frontiers in Pharmacology

Received: 21 September 2021 Accepted: 07 December 2021 Published: 04 January 2022

Citation:

Bai Y-I, Han L-I, Qian J-h and Wang H-z (2022) Molecular Mechanism of Puerarin Against Diabetes and its Complications.

Front. Pharmacol. 12:780419. doi: 10.3389/fphar.2021.780419
Diabetes is a non-communicable metabolic disease characterized by chronic hyperglycemia. It has become the third epidemic following cardiovascular diseases and tumors (Meng et al., 2017; Niu et al., 2017). The International Diabetes Federation (IDF) reported 463 million diabetic adults worldwide, and this figure is projected to reach 700 million by 2045 (Nanditha et al., 2016; Yan et al., 2018). Significant and persistent hyperglycemia can lead to dysfunction in various cell types (Wang $C$ et al., 2020), efficiently inducing complications such as nephropathy, retinopathy, angiocardiopathy, cerebrovascular diseases, and neuropathy (Fletcher et al., 2007; Cheng et al., 2015; Srivali et al., 2015; Cusi et al., 2017; Azmi et al., 2019). Diabetes treatment alongside a strict diet and exercise control exerts a pronounced effect on blood glucose control. However, undesirable side effects such as hypoglycemia, gastrointestinal reactions, liver damage, and lactic acidosis brought by antidiabetic agents are particularly concerned (Srivali et al., 2015), which are the crux of implementing patient compliance and result in unsatisfactory management of complications.

As the demand for and use of traditional Chinese medicine (TCM) continues to rise globally, remarkable antidiabetic effects and safety of TCM products have been reported. Among them, ge-gen in Chinese or Radix Puerariae (RP) is a powerful healing herb (sweet and cool) widely used in ancient China (Prasain et al., 2003; Zhou et al., 2014). According to Sheng Nong's Herbal Classic during the Han Dynasty, it has the effects of relieving restless thirst, vomiting, and stiffness, and pain in joints and clearing internal heat by enriching yin. Thus, various toxicity is relieved (Huang et al., 2018; Wei et al., 2020). It also has the action of reducing fever, producing fluid, and relieving diarrhea due to spleen deficiency (Zhi et al., 2018). RP has been reported for diabetes treatment for two thousand years, as evidenced by ancient records regarding TCMs (e.g., Yu Quan [jade-spring] pill, Xiao Ke [relieving-thirst] pill, Qiwei Baizhu [seven-ingredient] powder) for restless thirst. Overall, RP-related TCMs for hyperglycemia frequently used in ancient China showed a good effect on diabetes and its complications (Cao et al., 2006; Zan, 2010; Cai et al., 2014; Liu J et al., 2014; Wong et al., 2015; Zhao et al., 2015). The isoflavone Puerarin is the affective component of RP (Cao et al., 2006), which has been shown to protect against various pathophysiological processes, including angiocardiopathy, osteoporosis, inflammation, liver damage, cancers (Jiang, 2004), and diabetes (Wong et al., 2011). However, RP in diabetes treatment only received scant attention from the rest of the world. We 
aimed to provide an overview of the roles of Puerarin in protection against diabetes and related complications for better knowledge of RP in diabetes treatment.

Six electronic databases, including China National Knowledge Infrastructure (CNKI), Wanfang database, Chinese Scientific Journals Database (VIP), PubMed, EMBASE, and Cochrane Library, were searched from June 2001 to June 2021 for identifying eligible studies. No restriction on language or publication status was imposed. The following terms were used in a combination for the electronic search: Kudzu root, Kudzu, Pueraria Mirifica, Pueraria lobata, Puerarin, diabetes, diabetes complications, complications of diabetes, diabetic nephropathy, diabetic cardiomyopathy, diabetic retinopathy, diabetic macroangiopathy, diabetic peripheral neuropathy, DN, NC, DR, DM, DPN, randomized control, randomization, randomized clinical trials, RCT, and trails. Inclusion criteria were animal studies and possible signaling pathways, including protective effects against diabetic complications. A third reviewer solved any inconsistency. Manual searches were performed to identify relevant studies in the reference lists of the included studies.

\section{HYPOGLYCEMIC MECHANISM OF PUERARIN}

It is generally accepted that insulin resistance (IR) and defective $\beta$-cell secretions are the main links in the pathogenesis of diabetes and the mechanisms involved in regulating blood glucose through four organs: pancreas, liver, skeletal muscle, and adipose tissue. We attempted to explore the molecular mechanisms of glucose-lowering by Puerarin acting on the above four target organs.

\section{Pancreas}

The endocrine function of the pancreas is performed by the islets, which are the center of controlling the dynamic balance of blood glucose in the body and are an essential endocrine organ in the pancreatic tissue. Among them, $\beta$-cell is the primary cell of the islets and mainly secrete insulin. If insulin production is insufficient, or if IR occurs, it may lead to elevated blood glucose. Puerarin acts on the following molecular mechanisms of the pancreas to lower blood glucose.

\section{Enhance GLP-1R Signaling Pathway}

A recent report showed that chronic hyperglycemia could lead to the loss of the glucagon-like peptide-1 receptor (GLP-1R) from the cell surface and impairment of GLP-1R signaling (Yang et al., 2016a). Therefore, recovery of the GLP-1R expression itself and the GLP-1R signaling transduction might be a strategy for diabetic treatment (Tomita, 2016).

On one side, it has been shown that Puerarin rescued the $\beta$-cell failure and promoted $\beta$-cell proliferation through up-regulating GLP-1R expression, which enhanced GLP-1R signaling and activated its downstream target protein kinase B (Akt), which led to the inactivation of forkhead box transcription factor $\mathrm{O} 1$ (Foxo1) and Caspase-3 subsequently. Foxol acts as a transcription factor to inhibit pancreatic duodenum homeobox-1 (PDX-1) activity and mediate-cell dysfunction and apoptosis (Yang et al., 2016a). The caspase family of proteins is involved in inducing apoptosis (Liang et al., 2019). (Figure 1)

On the other hand, Puerarin induced $\beta$-cell replication and neogenesis in pancreatic ductal cells of HFD mice depended on GLP-1R expression in ductal cells together with activating $\beta$-catenin and STAT3, subsequently activated $\mathrm{Wnt} / \beta$-catenin and JAK2/STAT3, up-regulation of PDX-1 and Ngn3 expression, which up-regulation of TCFTL2 expression, that might be downstream effectors of the GLP-1R signaling cascade. Puerarin triggers the pancreatic ductal epithelial cell to $\beta$-cell conversion through activating GLP-1R/Wnt/STAT3 signaling cascade (Wang $\mathrm{T}$ et al., 2020). (Figure 1)

\section{Reduce the Generation of ROS}

As is known, mitochondrial oxidative stress is a crucial factor contributing to IR and $\beta$-cell dysfunction. Excess reactive oxygen species (ROS) could activate downstream apoptotic factors, including cytochrome $\mathrm{C}(\mathrm{Cyt}-\mathrm{C})$ and $\mathrm{AIF}$, and induce $\beta$-cell apoptosis (Liang et al., 2019).

As revealed by some study, Puerarin significantly decreased ROS generation, which might be mediated via increasing gene expression of ROS scavengers-MnSod and Gpx-1 (Li et al., 2014), subsequently up-regulated the anti-oxidant superoxide dismutase 2 (SOD2) and Gpx-1, and the anti-apoptotic $\beta$-cell lymphoma- 2 (Bcl-2), and decreased the pro-apoptotic Bcl-2-associated $\mathrm{X}$ (Bax), thus, reducted of oxidative stress to protects telomere length in pancreatic $\beta$-cell of diabetic rats, inhibited pancreatic $\beta$-cell apoptosis as evidenced (Li et al., 2014; Chen et al., 2017). Another mechanism is to decrease mitochondrial malondialdehyde (MDA) levels and increase superoxide dismutase (SOD) levels in the pancreas by reducing ROS production, thus restoring the $\mathrm{Na}, \mathrm{K}$ - or $\mathrm{Ca}^{2+}$-ATPase activity to protect the pancreas (Sun et al., 2011).

\section{Improve Caspase/AIF/Apoptosis Pathway}

The caspase family proteins increase the mitochondrial permeability, which then triggers Cyt-C release from the mitochondria. AIF is also a crucial factor responsible for mitochondrial apoptosis. Therefore, the Caspase/AIF/apoptosis pathway may be a new target of Puerarin for diabetes mellitus therapy (Liang et al., 2019).

It has been shown that Puerarin inhibited the mitochondrial permeability by down-regulating the expression of the caspase family proteins, which inhibited Cyt-C release from the mitochondria and inhibited the formation of apoptotic bodies, namely, Cyt-C/Apaf-1/pro-caspase- 9 complex, which inhibited the expression of Caspase-3, realized the purpose of preventing apoptosis of pancreatic cell apoptosis (Liang et al., 2019). On the other hand, Puerarin prevented pancreatic cell apoptosis by inducing the activation of $\mathrm{Bcl}-2$, a regulatory factor of AIF(Liang et al., 2019). Moreover, Puerarin suppressed the activation of apoptosis-related proteins, including poly ADPribose polymerase (PARP) and Caspase-3, subsequently inhibiting $\beta$-cell apoptosis (Li et al., 2014). (Figure 2) 


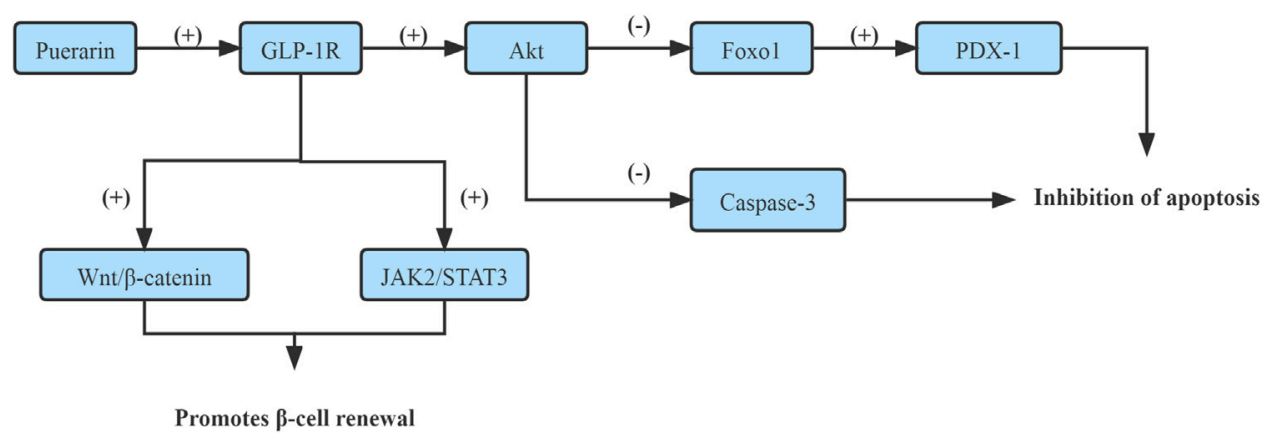

FIGURE 1 | Enhance GLP-1R signaling pathway.

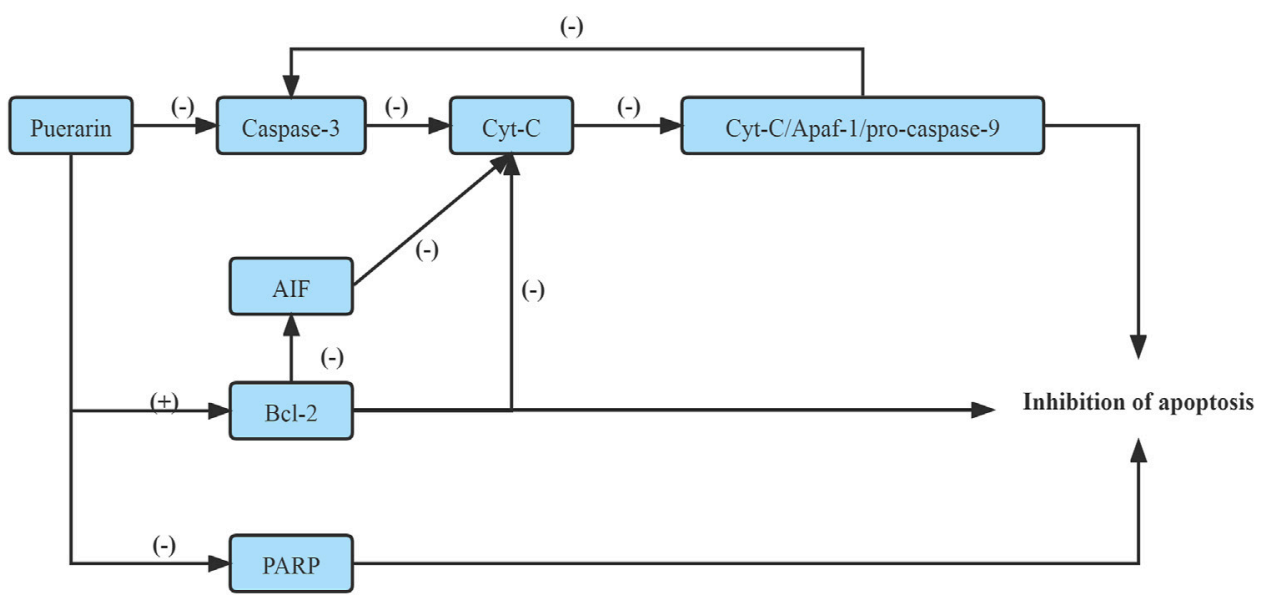

FIGURE 2 | Improve Caspase/AIF/apoptosis pathway.

\section{Improve PI3K/Akt Signaling Pathway}

The phosphoinositide 3-kinase (PI3K)/Akt signaling pathway regulates $\beta$-cell function and survival. Puerarin rapidly activated AKT phosphorylation and protected pancreatic $\beta$-cell survival by the PI3K/Akt signaling pathway, increasing pancreatic $\beta$-cell mass via $\beta$-cell apoptosis inhibition in diabetic mice (Li et al., 2014). (Figure 3)

Furthermore, Puerarin promoted $\beta$-EP synthesis in pancreatic tissue and activated pancreatic $\beta$-cell opioid receptors, which promoted insulin secretion (Chen et al., 2010a). Another mechanism is to inhibit the UCP2 gene expression via upregulating sirtuins1 (SIRT1) and AMP-Activated Protein Kinase (AMPK) protein expressions to protect pancreatic $\beta$-cell (Xiong et al., 2006; Chen et al., 2017).

Taken together, Puerarin increased $\beta$-cell mass and promoted $\beta$-cell survival through up-regulating GLP-1R expression, inhibiting ROS or Caspase/AIF/apoptosis pathway, increasing PI3K/Akt signaling pathway, which enhanced insulin receptor signaling and inhibited oxidative stress and $\beta$-cell apoptosis in the pancreas, subsequently, elevated serum insulin and improved IR, thus, lowered fasting blood glucose (FBG) and glycated hemoglobin (HbAlc) levels. The hypoglycemic mechanism of Pueraria acting on the pancreas is shown in Table 1.

\section{Skeletal Muscle and Adipose Tissue}

The skeletal muscle is the significant tissue of glucose metabolism, accounting for nearly $75 \%$ of the whole-body insulin-stimulated glucose uptake. IR in skeletal muscle is a critical component of the etiology of diabetes (Chen et al., 2018a). As the largest endocrine organ in the body, adipose tissue secretes various protein substances that regulate blood glucose metabolism and are essential regulators of human glucose homeostasis. Puerarin regulates blood glucose metabolism in skeletal muscle and adipose tissue through the following molecular mechanisms.

\section{Activate GLUT4 Transmission}

Glucose transport, which depends on insulin-stimulated translocation of glucose carriers to the cell membrane, is the rate-limiting step in carbohydrate metabolism of skeletal muscle and adipose tissue. The subtype 4 form is predominant in skeletal muscle and adipose tissue. It is possible that Puerarin can enhance glucose uptake and improve IR via increasing glucose 


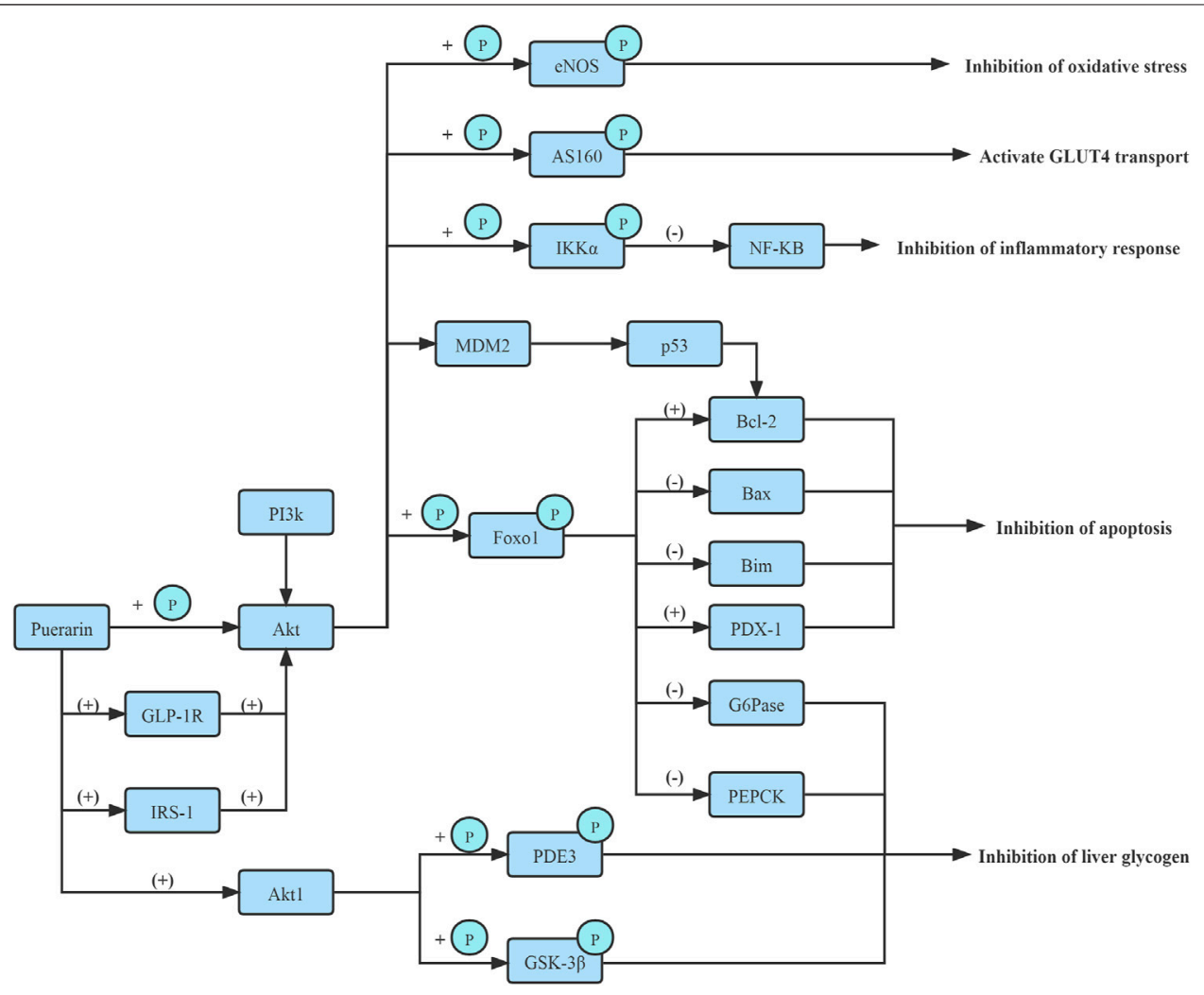

FIGURE 3 | Improve PI3K/Akt signaling pathway.

transporter 4 (GLUT4) mRNA and protein expressions (Hsu et al., 2003).

Numerous studies have reported that Puerarin increased GLUT4 mRNA and protein expressions on the plasma membrane in skeletal muscle and adipocyte membrane via improved insulin signaling protein, namely, protein kinase B (PKB/Akt), pronouncedly reduced IR and enhanced glucose absorption from blood circulation and lower blood sugar levels (Hsu et al., 2003; Song and Bi, 2004; Xu et al., 2005).

Moreover, Puerarin increased serum $\beta$-EP content via activating opioid $\mu$-receptor in adipocytes and skeletal muscle cell membrane, subsequently activating the phospholipase C-protein kinase C (PLC-PKC) pathway up-regulated the GLUT4 mRNA expression, thus promoting glucose uptake in adipose tissue and skeletal muscle tissue (Chen et al., 2010a).

In the skeletal muscle, insulin receptor signaling is achieved through insulin receptor substrate-1 (IRS-1), which coordinates PI3K-dependent activation of Akt. In vitro and in vivo experiments confirmed that Puerarin improved insulin signaling, namely, IRS-1, through activating $\mu$-opioid receptor, subsequently activated Akt, and phosphorylated its substrate AS160, and promoted GLUT4 translocation and glucose uptake (Chen et al., 2018a).

In addition, Puerarin could markedly improve the insulin resistance of 3T3-L1 lipocyte, which is realized possibly by way of activating for GLUT4 exocytosis via Cb1 signaling, promoting GLUT4 transposition to the cell membrane to increase the transportation of glucose, and improving IR, thus increasing insulin sensitivity and lowering blood glucose (Zhao and Zhou, 2012). Therefore, Puerarin improved the GLUT4 content of adipocytes in the IR state and promoted the translocation of intimal GLUT4 to the outer membrane, thereby increasing the transport and utilization of adipocytes to glucose (Li and $\mathrm{Bi}, 2004$ ).

Together, Puerarin activated GLUT4 transmission, thus improving IR, thereby increasing the transport and utilization of skeletal muscle cells and adipocytes to glucose (Figure 4).

\section{Activate PPAR Receptor Expressions}

On one side, intramuscular peroxisome proliferator-activated receptors a (PPAR $\alpha)$ activation promotes ingestion, utilization, and catabolism of fatty acids through activation of downstream genes (Wu et al., 2013). One of the main bio-functions of insulin receptors (InsR) promotes intracellular glucose uptake within target tissues and exerts a crucial physiological effect modulating glucose homeostasis. Therefore, Puerarin has been shown to upregulate InsR and PPARa mRNA expressions in the gastrocnemius via stimulating phosphodiesterase 3 (PDE3) and insulin-like growth factor-1 (IGF-1) to enhance insulin signaling and receptor sensitivity (Wu et al., 2013), promoted glucose uptake.

On the other hand, peroxisome proliferators-activated receptors $\gamma(\operatorname{PPAR} \gamma)$ is a ligand-activated nuclear transcription factor that is distributed in tissues with active energy metabolism, 
TABLE 1 | The hypoglycemic mechanism of Pueraria acting on the pancreas.

\begin{tabular}{|c|c|c|c|c|c|c|c|}
\hline Model & Assay & Species & Dose & Effect & Pathways (Target cells) & $\begin{array}{l}\text { Target } \\
\text { organs }\end{array}$ & References \\
\hline High-fat diet (HFD) & In vitro & $\begin{array}{l}\text { Male C57BL/6 } \\
\text { mice (4 weeks) }\end{array}$ & $\begin{array}{l}\text { Puerarin } \\
150 \mathrm{mg} / \mathrm{kg} \\
\text { for } 35 \mathrm{~d}\end{array}$ & $\begin{array}{l}\text { Puerarin promotes pancreatic } \\
\beta \text {-cell survival }\end{array}$ & $\begin{array}{l}\text { GLP-1R signaling pathway } \\
\text { (GLP-1R) }\end{array}$ & Pancreas & $\begin{array}{l}\text { Yang et al. } \\
\text { (2016a) }\end{array}$ \\
\hline High-fat diet (HFD) & In vitro & $\begin{array}{l}\text { Mice } \mathrm{db} / \mathrm{db} \text { (male, } \\
4 \text { weeks) }\end{array}$ & $\begin{array}{l}\text { Puerarin } \\
150 \mathrm{mg} / \mathrm{kg} / \mathrm{d} \\
\text { for } 55 \mathrm{~d}\end{array}$ & $\begin{array}{l}\text { Puerarin promotes pancreatic } \\
\beta \text {-cell survival }\end{array}$ & $\begin{array}{l}\text { GLP-1R signaling pathway } \\
(\text { GLP-1R) }\end{array}$ & Pancreas & $\begin{array}{l}\text { Yang et al. } \\
(2016 a)\end{array}$ \\
\hline $\begin{array}{l}\text { Diabetes induced by } \\
\text { STZ + High-fat diet (HFD) }\end{array}$ & In vivo & $\begin{array}{l}\text { Male Kunming } \\
\text { mice (18-22 g) }\end{array}$ & $\begin{array}{l}\text { Puerarin } \\
80 \mathrm{mg} / \mathrm{kg} \text { for } \\
15 \text { days (i.g.) }\end{array}$ & $\begin{array}{l}\text { Puerarin prevents apoptosis of } \\
\text { pancreatic cell apoptosis }\end{array}$ & $\begin{array}{l}\text { Caspase/AIF/apoptosis } \\
\text { signaling pathway (Bcl-2 } \\
\text { and the caspase family } \\
\text { proteins) }\end{array}$ & Pancreas & $\begin{array}{l}\text { Liang et al. } \\
\text { (2019) }\end{array}$ \\
\hline High-fat diet (HFD) & In vivo & $\begin{array}{l}\text { Male C57BL/6 } \\
\text { mice (5 weeks) }\end{array}$ & $\begin{array}{l}\text { Puerarin 150, } \\
300 \mathrm{mg} / \mathrm{kg} / \mathrm{d} \\
\text { for } 20 \mathrm{~d}\end{array}$ & $\begin{array}{l}\text { Puerarin induced } \beta \text {-cell } \\
\text { replication and neogenesis in } \\
\text { pancreatic ductal cells of HFD. }\end{array}$ & $\begin{array}{l}\text { GLP-1R/Wnt/STAT3 } \\
\text { signaling pathway } \\
\text { (GLP-1R) }\end{array}$ & Pancreas & $\begin{array}{l}\text { Wang T et al. } \\
(2020)\end{array}$ \\
\hline $\begin{array}{l}\text { Diabetes induced } \\
\text { by STZ }\end{array}$ & In vivo & $\begin{array}{l}\text { Male C57BL/6 } \\
\text { mice (8 weeks, } \\
20-22 \mathrm{~g})\end{array}$ & $\begin{array}{l}\text { Puerarin } \\
100 \mathrm{mg} / \mathrm{kg} \text { for } \\
3 \text { days before } \\
\text { STZ (i.p.) }\end{array}$ & $\begin{array}{l}\text { Puerarin acts directly on } \\
\text { pancreatic } \beta \text {-celll-protecting } \\
\text { function and survival and } \\
\text { protects pancreatic islet } \\
\text { survival by preventing } \beta \text {-cell } \\
\text { apoptosis }\end{array}$ & $\begin{array}{l}\text { Reduce the generation } \\
\text { of ROS } \\
\text { Caspase/AIF/apoptosis } \\
\text { signaling pathway (PARP } \\
\text { and Caspase-3); PI3K/Akt } \\
\text { signaling pathway (Akt) }\end{array}$ & Pancreas & Li et al. (2014) \\
\hline $\mathrm{CoCl} 2$ & In vitro & $\begin{array}{l}\text { Mouse insulinoma } \\
\text { MIN6 cells } \\
\text { (passage 22-30) }\end{array}$ & $\begin{array}{l}\text { Puerarin } 0.1,1 \\
10 \mathrm{mM} \text { for } 8 \mathrm{~h}\end{array}$ & $\begin{array}{l}\text { Puerarin acts directly on } \\
\text { pancreatic } \beta \text {-celll-protecting } \\
\text { function and survival and } \\
\text { protects pancreatic islet } \\
\text { survival by preventing } \beta \text {-cell } \\
\text { apoptosis }\end{array}$ & $\begin{array}{l}\text { Reduce the generation } \\
\text { of ROS } \\
\text { Caspase/AIF/apoptosis } \\
\text { signaling pathway (PARP } \\
\text { and Caspase-3); PI3K/Akt } \\
\text { signaling pathway (Akt) }\end{array}$ & Pancreas & Li et al. (2014) \\
\hline $\begin{array}{l}\text { Diabetes induced by } \\
\text { STZ + High-fat diet (HFD) }\end{array}$ & In vivo & $\begin{array}{l}\text { Male SD rats } \\
(160-180 \mathrm{~g})\end{array}$ & $\begin{array}{l}\text { Puerarin } \\
80 \mathrm{mg} / \mathrm{kg} \text { for } \\
4 \text { weeks (i.p.) }\end{array}$ & $\begin{array}{l}\text { Puerarin exerts preventive and } \\
\text { remedial effects on the diabetic } \\
\text { pancreatic } \beta \text {-cell, which is } \\
\text { probably due to protecting } \\
\text { telomere length and inhibiting } \\
\beta \text {-cell apoptosis via alleviating } \\
\text { oxidative damage }\end{array}$ & $\begin{array}{l}\text { Reduce the generation of } \\
\text { ROS; SIRT1/AMPK } \\
\text { signaling pathway }\end{array}$ & Pancreas & $\begin{array}{l}\text { Chen et al. } \\
(2017)\end{array}$ \\
\hline $\begin{array}{l}\text { Proteoxypyrimidine } \\
\text { solution }\end{array}$ & In vivo & $\begin{array}{l}\text { Wistar rats ( } 8 \\
\text { weeks, } \\
180-240 \mathrm{~g})\end{array}$ & $\begin{array}{l}\text { Puerarin } \\
80 \mathrm{mg} / \mathrm{kg} / \mathrm{d} \\
\text { (i.p., } \mathrm{n}=10 \text { ) }\end{array}$ & Puerarin protects the pancreas & $\begin{array}{l}\text { Reduce the generation } \\
\text { of ROS }\end{array}$ & Pancreas & $\begin{array}{l}\text { Sun et al. } \\
(2011)\end{array}$ \\
\hline $\begin{array}{l}\text { Diabetes induced } \\
\text { by STZ }\end{array}$ & In vivo & $\begin{array}{l}\text { Male SD rats }(6 \\
\text { weeks, } \\
180-220 \mathrm{~g})\end{array}$ & $\begin{array}{l}\text { Puerarin } 80,120 \text {, } \\
160 \mathrm{mg} / \mathrm{kg} \text { for } \\
12 \text { weeks }\end{array}$ & $\begin{array}{l}\text { Puerarin promoted } \beta \text {-EP } \\
\text { synthesis in pancreatic tissue } \\
\text { and activated pancreatic } \beta \text {-cell } \\
\text { opioid receptors, which } \\
\text { promoted insulin secretion }\end{array}$ & $\begin{array}{l}\text { opioid receptors signaling } \\
\text { pathway (opioid receptors) }\end{array}$ & Pancreas & $\begin{array}{l}\text { Chen et al. } \\
\text { (2010a) }\end{array}$ \\
\hline $500 \mathrm{mM} \mathrm{H} 2 \mathrm{O} 2$ & In vitro & $\begin{array}{l}\text { Male Wistar rats } \\
\text { pancreatic islets }\end{array}$ & $\begin{array}{l}\text { Puerarin } 100 \mathrm{mM} \\
\text { for } 48 \mathrm{~h}\end{array}$ & Puerarin protects the pancreas & $\begin{array}{l}\text { SIRT1/AMPK signaling } \\
\text { pathway }\end{array}$ & Pancreas & $\begin{array}{l}\text { Xiong et al. } \\
(2006)\end{array}$ \\
\hline
\end{tabular}

such as adipose and skeletal muscle and is mainly involved in the regulation of insulin sensitivity, adipocyte differentiation, and the expression of many genes related to glucolipid metabolism. The mechanism of Puerarin could activate PPAR $\gamma$ through stimulating PPAR $\gamma$ mRNA expression, and then increased the heterodimer of PPAR $\gamma$ and retinoic acid receptor (RXR), which can bind to response elements present in target genes activated by these transcription factors, subsequently potentiated preadipocyte differentiation, and improved IR and insulin sensitivity, which potentiated the glucose-uptake of adipocytes, in vivo and in vitro assays. Further investigations are needed to confirm this suggestion (Xu et al., 2005).

\section{Promote Fatty Acid Oxidation}

In addition, growing evidence suggested that mitochondrial dysfunction and the associated impairment of the oxidative capacity of skeletal muscle contribute to the development of insulin resistance. Thus, the improvement of mitochondrial function and fatty acid oxidation in muscle is regarded as a potential therapeutic approach for the treatment of diabetes (Chen et al., 2018b).

In vivo and in vitro assays, Puerarin protected mitochondria of skeletal muscle against oxidative damage via increasing sirtuins 3(SIRT3) and SOD2 expressions and suppressing p66Shc phosphorylation, which led to promoted the oxidation of fatty acids, which thus prevented the accumulation of intramyocellular lipids (IMCLs) in diabetic rats (Chen et al., 2018b). As for puerarin-mediated adipocyte IR inhibition, the administration of Puerarin significantly decreased membrane levels of fatty acid translocase (CD36) and increased the phosphorylation of AMPK and acetyl carboxylase (ACC) to enhance the activity of carnitine palmitoyltransferase-1b (CPT-1b), which thus reduced the 


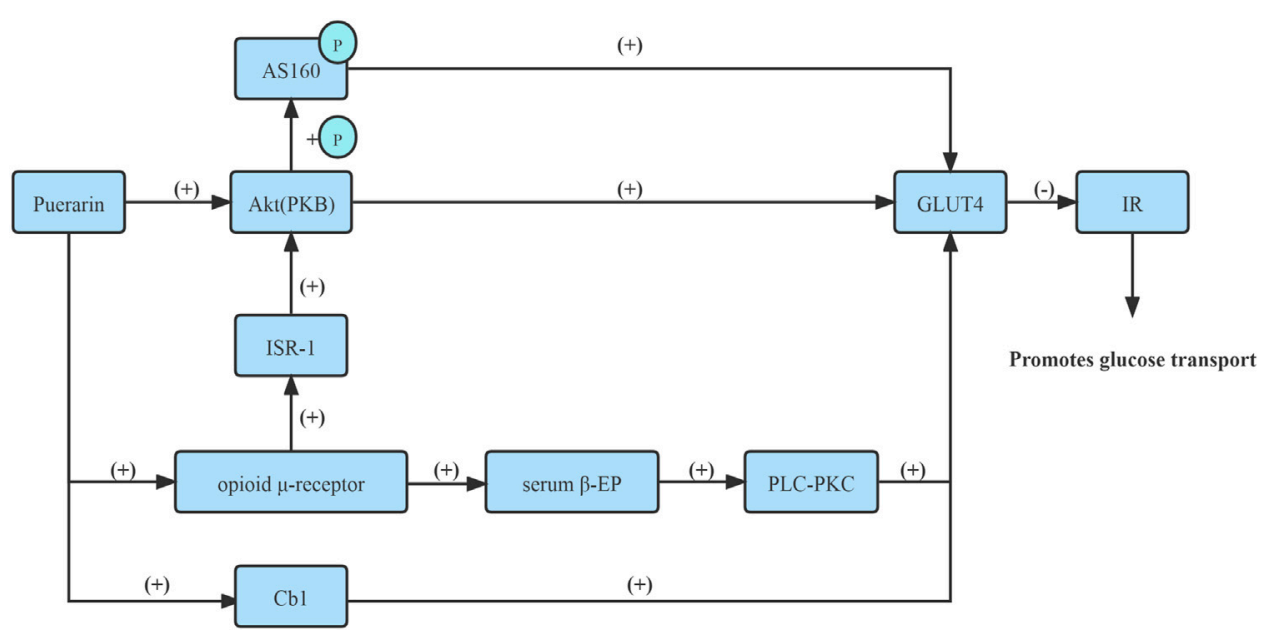

FIGURE 4 | Activate GLUT4 transmission.

uptake of fatty acids, promoted the transport of fatty acids into mitochondria for oxidation, and prevented the accumulation of IMCLs (Chen et al., 2018b). In-vitro experiments show that Puerarin fueled fatty acid oxidation in myotubes against lipid accumulation, which suppressed membrane CD36 levels and reduced IR (Chen et al., 2018b).

In conclusion, Puerarin could improve IR and enhance glucose uptake by increasing GLUT4 transport, activating PPAR receptor expressions, and promoting fatty acid oxidation in skeletal muscle cells and adipocytes, thus lowering blood sugar. The hypoglycemic mechanism of Puerarin acting on the skeletal muscle and adipose tissue is shown in Table 2.

\section{Liver}

The pathophysiological mechanism of elevated blood glucose involves a variety of tissues and cells, of which the liver has the most closed relationship with type 2 diabetes. The liver plays a crucial role in glucose metabolism. The regulation of glucose production and storage by the liver is crucial for gluconeogenesis and glycogen synthesis. The most important source of endogenous glucose production in hepatic gluconeogenesis, a hallmark in type 2 diabetes patients (Liu et al., 2021).

The PI3K/Akt signaling pathway is considered the foremost signal transduction pathway and plays a significant regulatory role in gluconeogenesis. Glucose-6-phosphatase (G6pase) and phosphoenolpyruvate carboxykinase (PEPCK) are the pivotal rate-limiting enzymes in gluconeogenesis, and Foxo1 modulates insulin sensitivity. Under the condition of insulin resistance, PI3K/Akt activity is decreased, and hepatic gluconeogenesis is promoted due to increased PEPCK and G6pase expression driven by Foxo1 (Liu et al., 2021).

In vitro and in vivo experiments confirm, Puerarin could enhance the phosphorylation of Foxol by activating PI3K/Akt signaling pathway in liver tissues of type 2 diabetes rates and elevating the pFoxo1/Foxo1 protein and mRNA expressions, and further inhibiting the expression of G6pase and PEPCK. Thus hepatic gluconeogenesis and endogenous glucose production in the liver are suppressed. Furthermore, Puerarin improved IR (Shen et al., 2019; Liu et al., 2021). (Figure 3)

Moreover, in vitro, the protein kinase $\mathrm{B} \alpha 2$ (Akt1) is predicted to be a target protein of Puerarin. Puerarin targeted the $\mathrm{PH}$ domain of Akt1, inhibited Akt1's transmembrane effect, and activated Akt1 to improve the phosphorylation or activity of downstream proteins, such as glycogen synthase kinase-3 $\beta$ (GSK$3 \beta$ ) and PDE3, and ultimately regulated glucose and lipid metabolism (Shen et al., 2019). (Figure 3)

Consequently, Puerarin inhibits hepatic gluconeogenesis by activating PI3K/Akt signaling pathway. The hypoglycemic mechanism of Pueraria acting on the liver is shown in Table 3.

Finally, Puerarin regulates systemic functions to lower blood sugar. In vitro and in vivo studies prove that the antidiabetic effects of Puerarin might be related to the inhibition of protein tyrosine phosphatase-1B.

(PTP1B), therefore, better the insulin signaling pathway and increased insulin receptor's, achieving the purpose of moderating blood glucose levels by markedly boosting glucose uptake and escalating glucose tolerance (Sun et al., 2019). Moreover, Puerarin significantly increased plasma $\beta$-endorphin $(\beta$-EP) concentrations and reduced blood glucose levels in diabetic rats via within $\alpha 1$-adrenergic receptors ( $\alpha 1-\mathrm{AR})$ and adrenal medulla 1-adrenaline (1-A) activation (Chen et al., 2004). In addition, Puerarin decreased the level of blood glucose and aldose reductase activity in red blood cells, accordingly inhibiting the formation of glycation products and expression of AGE mRNA (Kim et al., 2006; Zhang et al., 2006; Zhang et al., 2009; Liu et al., 2018). See Table 4 for details.

\section{PROTECTIVE MECHANISM OF PUERARIA AGAINST DIABETIC COMPLICATIONS}

Diabetic complications are based on long-term chronic hyperglycemia, which damages small, medium, large, and 
TABLE 2 | The hypoglycemic mechanism of Puerarin acting on the skeletal muscle and adipose tissue.

\begin{tabular}{|c|c|c|c|c|c|c|c|}
\hline Model & Assay & Species & Dose & Effect & $\begin{array}{c}\text { Pathways (Target } \\
\text { cells) }\end{array}$ & $\begin{array}{l}\text { Target } \\
\text { organ }\end{array}$ & References \\
\hline Diabetes induced by STZ & In vivo & $\begin{array}{l}\text { Male SD rats }(6 \\
\text { weeks, } 180-220 \mathrm{~g})\end{array}$ & $\begin{array}{l}\text { Puerarin } 80,120 \text {, } \\
160 \mathrm{mg} / \mathrm{kg} \text { for } \\
12 \text { weeks }\end{array}$ & $\begin{array}{l}\text { Puerarin increases serum } \\
\beta \text {-EP content and promotes } \\
\text { the uptake of glucose by fat } \\
\text { and skeletal muscle tissues }\end{array}$ & $\begin{array}{l}\text { Activate GLUT4 } \\
\text { transport (opioid } \\
\mu \text {-receptor) }\end{array}$ & $\begin{array}{l}\text { Skeletal } \\
\text { muscle and } \\
\text { adipose } \\
\text { tissue }\end{array}$ & $\begin{array}{l}\text { Chen et al. } \\
\text { (2010a) }\end{array}$ \\
\hline High-fat diet (HFD) & In vivo & $\begin{array}{l}\text { Male SD rats } \\
(160-180 \mathrm{~g})\end{array}$ & $\begin{array}{l}\text { Puerarin } 100 \text { mg/kg } \\
\text { for } 4 \text { weeks (i.p.) }\end{array}$ & $\begin{array}{l}\text { Puerarin enhances } \mu \text {-opioid } \\
\text { receptor expression and } \\
\text { phosphorylation and } \\
\text { increases insulin-stimulated } \\
\text { GUT4 translocation to the } \\
\text { plasma membrane in the } \\
\text { skeletal muscle of diabetic } \\
\text { rats }\end{array}$ & $\begin{array}{l}\text { Activate GLUT4 } \\
\text { transport (opioid } \\
\mu \text {-receptor) }\end{array}$ & $\begin{array}{l}\text { Skeletal } \\
\text { muscle }\end{array}$ & $\begin{array}{l}\text { Chen et al. } \\
(2018 \mathrm{a})\end{array}$ \\
\hline $0.75 \mathrm{mM}$ of palmitate & In vitro & $\begin{array}{l}\text { Rat L6 skeletal } \\
\text { muscle cells }\end{array}$ & $\begin{array}{l}0.3 \mathrm{mM} \text { puerarin } \\
\text { for } 24 \mathrm{~h}\end{array}$ & $\begin{array}{l}\text { Puerarin affects insulin } \\
\text { sensitivity in the muscle in a } \\
\mu \text {-opioid receptor- } \\
\text { dependent manner in vitro }\end{array}$ & $\begin{array}{l}\text { Activate GLUT4 } \\
\text { transport (opioid } \\
\mu \text {-receptor) }\end{array}$ & $\begin{array}{l}\text { Skeletal } \\
\text { muscle }\end{array}$ & $\begin{array}{l}\text { Chen et al. } \\
\text { (2018a) }\end{array}$ \\
\hline Diabetes induced by STZ & In vitro & $\begin{array}{l}\text { Isolated soleus } \\
\text { muscle of STZ- } \\
\text { diabetic male Wistar } \\
\text { rats }(200-250 \mathrm{~g})\end{array}$ & $\begin{array}{l}\text { Puerarin } \\
0.01-100 \mathrm{~mol} / \mathrm{L}\end{array}$ & $\begin{array}{l}\text { Puerarin enhances glucose } \\
\text { uptake }\end{array}$ & $\begin{array}{l}\text { Activate GLUT4 } \\
\text { transport (PKB/Akt) }\end{array}$ & $\begin{array}{l}\text { Skeletal } \\
\text { muscle }\end{array}$ & $\begin{array}{l}\text { Hsu et al. } \\
(2003)\end{array}$ \\
\hline Diabetes induced by STZ & In vivo & $\begin{array}{l}\text { Male Wistar rats } \\
(200-250 \mathrm{~g})\end{array}$ & $\begin{array}{l}\text { Puerarin } 5-20 \mathrm{mg} / \mathrm{kg} / \\
\mathrm{d} \text { (i.v., } \mathrm{n}=8 \text { ); } \\
15 \mathrm{mg} / \mathrm{kg} \text { (i.v., } \mathrm{n}=8 \text { ) } \\
\text { three times daily for } \\
3 \text { days }\end{array}$ & $\begin{array}{l}\text { Puerarin up-regulates } \\
\text { GLUT-4 mRNA and protein } \\
\text { expression in soleus muscle } \\
\text { and enhances glucose } \\
\text { uptake }\end{array}$ & $\begin{array}{l}\text { Activate GLUT4 } \\
\text { transport (PKB/Akt) }\end{array}$ & $\begin{array}{l}\text { Skeletal } \\
\text { muscle }\end{array}$ & $\begin{array}{l}\text { Hsu et al. } \\
(2003)\end{array}$ \\
\hline High glucose & In vitro & $\begin{array}{l}\text { Preadipocytes of } \\
\text { male SD rats } \\
(100-150 \mathrm{~g})\end{array}$ & $\begin{array}{l}\text { Puerarin } 3,10 \\
30 \mathrm{~mol} / \mathrm{L} \text { for } 48 \mathrm{~h}\end{array}$ & $\begin{array}{l}\text { Puerarin can potentiate } \\
\text { glucose uptake of insulin } \\
\text { resistance adipocytes } \\
\text { induced by high glucose } \\
\text { treatment in a dose- } \\
\text { dependent manner }\end{array}$ & $\begin{array}{l}\text { Activate GLUT4 } \\
\text { transport (PKB/Akt) }\end{array}$ & $\begin{array}{l}\text { Adipose } \\
\text { tissue }\end{array}$ & $\begin{array}{l}\text { Xu et al. } \\
(2005)\end{array}$ \\
\hline DMEM & In vitro & $\begin{array}{l}\text { HUVECs of male SD } \\
\text { rats }(100-150 \mathrm{~g})\end{array}$ & $\begin{array}{l}\text { Puerarin } 3,10 \text {, } \\
30 \mathrm{~mol} / \mathrm{L} \text { for } 3 \text { days }\end{array}$ & $\begin{array}{l}\text { Puerarin potentiates insulin- } \\
\text { induced preadipocyte } \\
\text { differentiation, promotes } \\
\text { glucose uptake of } \\
\text { adipocytes that have been } \\
\text { induced insulin resistance } \\
\text { by high glucose }\end{array}$ & $\begin{array}{l}\text { Activate GLUT4 } \\
\text { transport (PKB/Akt); } \\
\text { Activate PPAR } \\
\text { receptor } \\
\text { expressions } \\
(\text { PPAR } \gamma)\end{array}$ & $\begin{array}{l}\text { Adipose } \\
\text { tissue }\end{array}$ & $\begin{array}{l}\text { Xu et al. } \\
(2005)\end{array}$ \\
\hline $\begin{array}{l}\text { Hypercholesterolemic } \\
\text { diet }\end{array}$ & In vivo & $\begin{array}{l}\text { Male SD rats } \\
(150-200 \mathrm{~g})\end{array}$ & $\begin{array}{l}\text { Puerarin } 100 \text { mg/kg/d } \\
\text { for } 4 \text { weeks (i.p., } n=8 \text { ) }\end{array}$ & $\begin{array}{l}\text { Puerarin reduces blood } \\
\text { glucose and insulin levels } \\
\text { and up-regulates the protein } \\
\text { expression of GLUT-4 in } \\
\text { skeletal muscle }\end{array}$ & $\begin{array}{l}\text { Activate GLUT4 } \\
\text { transport (PKB/Akt) }\end{array}$ & $\begin{array}{l}\text { Skeletal } \\
\text { muscle }\end{array}$ & $\begin{array}{l}\text { Song and } \mathrm{Bi} \text {, } \\
(2004)\end{array}$ \\
\hline FFA & In vitro & $\begin{array}{l}\text { Preadipocyte line } \\
\text { 3T3-L1 }\end{array}$ & $\begin{array}{l}\text { Puerarin } 1.5,0.75 \mathrm{mg} / \\
\mathrm{ml} \text { for } 48 \mathrm{~h}\end{array}$ & $\begin{array}{l}\text { Puerarin improves insulin } \\
\text { resistance and increases the } \\
\text { transportation of glucose of } \\
\text { 3T3-L1 lipocytes }\end{array}$ & $\begin{array}{l}\text { Activate GLUT4 } \\
\text { transport (Cb1) }\end{array}$ & $\begin{array}{l}\text { Adipose } \\
\text { tissue }\end{array}$ & $\begin{array}{l}\text { Zhao and } \\
\text { Zhou, (2012) }\end{array}$ \\
\hline $\begin{array}{l}\text { High glucose + High-fat } \\
\text { diet (HFD) }\end{array}$ & In vivo & $\begin{array}{l}\text { Male Wistar rats (6 } \\
\text { weeks, } 165-180 \mathrm{~g} \text { ) }\end{array}$ & $\begin{array}{l}\text { Puerarin } 100 \text { mg/kg } \\
\text { for } 6 \text { weeks (i.p., n } \\
=10 \text { ) }\end{array}$ & $\begin{array}{l}\text { Puerarin increases the } \\
\text { transport and utilization of } \\
\text { adipocytes to glucose }\end{array}$ & $\begin{array}{l}\text { Activate GLUT4 } \\
\text { transport }\end{array}$ & $\begin{array}{l}\text { Adipose } \\
\text { tissue }\end{array}$ & $\begin{array}{l}\mathrm{Li} \text { and } \mathrm{Bi} \text {, } \\
(2004)\end{array}$ \\
\hline Diabetes induced by STZ & In vivo & $\begin{array}{l}\text { Male BALB/c mice } \\
(180-200 \mathrm{~g})\end{array}$ & $\begin{array}{l}\text { Puerarin } 20,40, \\
80 \mathrm{mg} / \mathrm{kg} \text { for } 14 \mathrm{~h}\end{array}$ & $\begin{array}{l}\text { Puerarin up-regulates the } \\
\text { InsR, PPARa mRNA } \\
\text { expressions of } \\
\text { gastrocnemius in diabetic } \\
\text { mice }\end{array}$ & $\begin{array}{l}\text { Activate PPAR } \\
\text { receptor } \\
\text { expressions (PDE3 } \\
\text { and IGF-1) }\end{array}$ & $\begin{array}{l}\text { Skeletal } \\
\text { muscle }\end{array}$ & $\begin{array}{l}\text { Wu et al. } \\
(2013)\end{array}$ \\
\hline $\begin{array}{l}\text { Diabetes induced by STZ } \\
+ \text { High-fat diet (HFD) }\end{array}$ & In vivo & $\begin{array}{l}\text { Male SD rats (6 } \\
\text { weeks) }\end{array}$ & $\begin{array}{l}\text { Puerarin } 100 \mathrm{mg} / \mathrm{kg} \\
\text { for } 4 \text { weeks (i.p.) }\end{array}$ & $\begin{array}{l}\text { Puerarin effectively alleviates } \\
\text { dyslipidemia and decreases } \\
\text { the accumulation of } \\
\text { intramyocellular lipids }\end{array}$ & $\begin{array}{l}\text { Promote fatty acid } \\
\text { oxidation (SIRT3 } \\
\text { and SOD2) }\end{array}$ & $\begin{array}{l}\text { Skeletal } \\
\text { muscle }\end{array}$ & $\begin{array}{l}\text { Chen et al. } \\
\text { (2018b) }\end{array}$ \\
\hline $\begin{array}{l}\text { DMEM+0.75 mM } \\
\text { palmitate }\end{array}$ & In vitro & $\begin{array}{l}\text { Rat L6 skeletal } \\
\text { muscle cells }\end{array}$ & $\begin{array}{l}\text { Puerarin }(0.3 \mathrm{mM}) \\
\text { for } 24 \mathrm{~h}\end{array}$ & $\begin{array}{l}\text { Puerarin effectively alleviates } \\
\text { dyslipidemia and decreases } \\
\text { the accumulation of } \\
\text { intramyocellular lipids }\end{array}$ & $\begin{array}{l}\text { Promote fatty acid } \\
\text { oxidation (CD36) }\end{array}$ & $\begin{array}{l}\text { Skeletal } \\
\text { muscle }\end{array}$ & $\begin{array}{l}\text { Chen et al. } \\
\text { (2018b) }\end{array}$ \\
\hline
\end{tabular}


TABLE 3 | The hypoglycemic mechanism of Pueraria acting on the liver.

\begin{tabular}{|c|c|c|c|c|c|c|c|}
\hline Model & Assay & Species & Dose & Effect & $\begin{array}{l}\text { Pathways } \\
\text { (Target cells) }\end{array}$ & $\begin{array}{l}\text { Target } \\
\text { organ }\end{array}$ & References \\
\hline $\begin{array}{l}\text { Diabetes induced by } \\
\text { STZ + High-fat } \\
\text { diet (HFD) }\end{array}$ & In vivo & $\begin{array}{l}\text { Male Wistar rats } \\
(160-200 \mathrm{~g})\end{array}$ & $\begin{array}{l}\text { Puerarin } \\
300 \mathrm{mg} / \mathrm{kg} / \mathrm{d} \text { for } \\
4 \text { weeks (p.o.) }\end{array}$ & $\begin{array}{l}\text { Puerarin administration improves glucose } \\
\text { tolerance and inhibits hepatic } \\
\text { gluconeogenesis in T2DM rats }\end{array}$ & $\begin{array}{l}\text { PI3K/Akt signaling } \\
\text { pathway (Akt) }\end{array}$ & Liver & $\begin{array}{l}\text { Liu et al. } \\
(2021)\end{array}$ \\
\hline PA & In vitro & HepG2 & $\begin{array}{l}\text { Puerarin 10, } 100 \text {, } \\
1,000 \mu \mathrm{mol} / \mathrm{L}\end{array}$ & $\begin{array}{l}\text { Puerarin administration improves glucose } \\
\text { tolerance and inhibits hepatic } \\
\text { gluconeogenesis in T2DM rats }\end{array}$ & $\begin{array}{l}\text { PI3K/Akt signaling } \\
\text { pathway (Akt) }\end{array}$ & Liver & $\begin{array}{l}\text { Liu et al. } \\
(2021)\end{array}$ \\
\hline DMSO & In vitro & HepG2 & $\begin{array}{l}\text { Puerarin } 10-5 \mathrm{~mol} / \mathrm{L} \\
\text { for } 24 \mathrm{~h}\end{array}$ & $\begin{array}{l}\text { Puerarin regulates glucose and lipid } \\
\text { metabolism }\end{array}$ & $\begin{array}{l}\text { PI3K/Akt signaling } \\
\text { pathway (Akt1) }\end{array}$ & Liver & $\begin{array}{l}\text { Shen et al. } \\
\text { (2019) }\end{array}$ \\
\hline
\end{tabular}

TABLE 4 | Hypoglycemic mechanism of Pueraria acting on systemic functions.

\begin{tabular}{|c|c|c|c|c|c|c|c|}
\hline Model & Assay & Species & Dose & Effect & $\begin{array}{c}\text { Pathways (Target } \\
\text { cells) }\end{array}$ & $\begin{array}{l}\text { Target } \\
\text { organ }\end{array}$ & References \\
\hline $\begin{array}{l}\text { Insulin-resistant } \\
\text { HepG2 cells }\end{array}$ & In vitro & $\begin{array}{l}\text { Insulin-resistant } \\
\text { HepG2 cells }\end{array}$ & $\begin{array}{l}\text { Puerarin }(0.0115 \text {, } \\
0.0058,0.0029 \text {, } \\
0.0014 \mathrm{mg} / \mathrm{ml})\end{array}$ & $\begin{array}{l}\text { Puerarin increases the insulin } \\
\text { sensitivity in HepG } 2 \text { cells and } \\
\text { enhances the glucose uptake, and } \\
\text { betters the insulin signaling pathway }\end{array}$ & $\begin{array}{l}\text { Inhibition PTP1B } \\
\text { (PTP1B) }\end{array}$ & $\begin{array}{l}\text { Systemic } \\
\text { function }\end{array}$ & $\begin{array}{l}\text { Sun et al. } \\
\text { (2019) }\end{array}$ \\
\hline $\begin{array}{l}\text { Diabetes } \\
\text { induced by STZ }\end{array}$ & In vivo & $\begin{array}{l}\text { Male C57BL/6 } \\
\text { mice ( } 4 \text { weeks, } \\
18-22 \text { g) }\end{array}$ & $\begin{array}{l}\text { Puerarin }(0.25,0.5 \\
1,2 \mathrm{~g} / \mathrm{kg})\end{array}$ & Puerarin escalates glucose tolerance & $\begin{array}{l}\text { Inhibition PTP1B } \\
\text { (PTP1B) }\end{array}$ & $\begin{array}{l}\text { Systemic } \\
\text { function }\end{array}$ & $\begin{array}{l}\text { Sun et al. } \\
\text { (2019) }\end{array}$ \\
\hline $\begin{array}{l}\text { Diabetes } \\
\text { induced by STZ }\end{array}$ & In vitro & $\begin{array}{l}\text { Male Wistar rats } \\
(200-250 \mathrm{~g})\end{array}$ & $\begin{array}{l}\text { Puerarin } 15 \text { mg/kg } \\
\text { (i.v., } \mathrm{n}=8 \text { ) }\end{array}$ & $\begin{array}{l}\text { Puerarin reduces blood glucose level } \\
\text { and enhanced plasma-endorphin } \\
\text { level in the absence of insulin } \\
\text { stimulation }\end{array}$ & $\begin{array}{l}\text { Activate the } 1-A \text { or } a 1- \\
\text { AR-mediated signalings } \\
(1-A \text { or } \alpha 1-A R)\end{array}$ & $\begin{array}{l}\text { Systemic } \\
\text { function }\end{array}$ & $\begin{array}{l}\text { Chen et al. } \\
(2004)\end{array}$ \\
\hline D-galactose & In vivo & SD rats (6 weeks) & $\begin{array}{l}\text { Puerarin } 75,150 \text {, } \\
300 \mathrm{mg} / \mathrm{kg} \text { for } \\
6 \text { weeks (i.g.) }\end{array}$ & $\begin{array}{l}\text { Puerarin decreases the level of blood } \\
\text { glucose and the activity of aldose } \\
\text { reductase in red blood cells, inhibiting } \\
\text { the formation of glycation products }\end{array}$ & $\begin{array}{l}\text { Inhibition of AGEs } \\
\text { formation }\end{array}$ & $\begin{array}{l}\text { Systemic } \\
\text { function }\end{array}$ & $\begin{array}{l}\text { Zhang et al. } \\
\text { (2006) }\end{array}$ \\
\hline
\end{tabular}

microvessels and causes organ lesions. Chronic hyperglycemia, as a specific characterization of diabetes, has adverse effects on various organs such as the kidney, eyes, heart, and especially nervous, easily caused by diabetic nephropathy (DN), diabetic macroangiopathy (DM), diabetic retinopathy (DR), diabetic cardiomyopathy (DC), diabetic peripheral neuropathy (DPN) and so on. Puerarin has a protective effect against the above diabetic complications. The protective mechanism of Puerarin against diabetic complications is shown in Table 5.

\section{Diabetic Nephropathy}

Some studies discovered that reduction of NAD + profile was induced by hyperglycemia in the podocytes. Following the condition, the expression levels of SIRT1 and peroxisome proliferator-activated receptor $\gamma$ coactivator-1a (PGC-1 $\alpha$ ) were decreased, and mitochondrial damage occurred (Xu et al., 2016). Puerarin reduced oxidative stress by activating SIRT1. SIRT1 serves as a regulator of Foxo1, Puerarin activated downstream pathway of Foxo1 through activating SIRT1, accordingly stimulated the synthesis of PGC-1 $\alpha$, subsequently elevated the anti-oxidant target gene MnSOD and catalase (CAT) by SIRT1/Foxo1 pathway, and driven the anti-oxidant effect, may lead to a reduction of ROS, meanwhile, down-regulation of IL-6, TNF- $\alpha$ in the kidney (Xu et al., 2016). On the other hand, Puerarin regulated NADPH oxidase 4 (NOX4) expression through the SIRT1-NF- $\mathrm{B}$ pathway in podocytes. Puerarin decreased nuclear factor kappa-light-chain-enhancer of activated $\beta$-cells $(\mathrm{NF}-\kappa \mathrm{B})$ activation through activating SIRT1, subsequently restrained release to proinflammatory cytokines, and decreased NOX4 expression, the primary enzyme contributing to the increased oxidative stress in podocytes among the different NADPH oxidase (NOX) isoforms, thus reduced oxidative stress ( $\mathrm{Xu}$ et al., 2016; Li et al., 2017). It also acted directly on nuclear factor-kBp65 (NF-kBp65) and reduced tumor necrosis factor- $\alpha$ (TNF- $\alpha$ ) expression by downregulating NF-kBp65 expression in kidney tissue (Cui and Wang, 2010). Alternatively, it acted directly on intercellular cell adhesion molecule-1 (ICAM-1) and TNF- $\alpha$ and inhibited expressions of ICAM-1 and TNF- $\alpha$, inhibited non-enzymatic glycosylation of proteins, and relieved oxidative stress inflammatory reaction damage (Pan et al., 2015).

On the other hand, transforming growth factor- $\beta 1$ (TGF- $\beta 1$ ) is one of the probiotic growth factors. A high blood glucose level can induce broad expression of the TGF- $\beta 1$ gene and protein in the kidney (She et al., 2014). Excessive activation of the TGF- $\beta 1 /$ 
TABLE 5 | The protective mechanism of Puerarin against diabetic complications.

\begin{tabular}{|c|c|c|c|c|c|c|c|}
\hline Model & Assay & Species & Dose & $\begin{array}{l}\text { Protective } \\
\text { mechanism }\end{array}$ & $\begin{array}{c}\text { Pathways (Target } \\
\text { cells) }\end{array}$ & $\begin{array}{l}\text { Diabetes } \\
\text { complications }\end{array}$ & References \\
\hline $\begin{array}{l}\text { Diabetes induced } \\
\text { by STZ }\end{array}$ & In vivo & $\begin{array}{l}\text { Male C57BL/6 mice } \\
(18-22 \mathrm{~g})\end{array}$ & $\begin{array}{l}\text { Puerarin 20, } 40 \text {, } \\
80 \mathrm{mg} / \mathrm{kg} / \mathrm{d} \text { for } \\
8 \text { weeks (i.g., } \mathrm{n}=10 \text { ) }\end{array}$ & $\begin{array}{l}\text { Anti-oxidative } \\
\text { stress; Anti- } \\
\text { inflammatory }\end{array}$ & $\begin{array}{l}\text { SIRT1/Foxo1 pathway } \\
\text { (SIRT1); SIRT1-NF-кB } \\
\text { pathway (SIRT1) }\end{array}$ & $\begin{array}{l}\text { Diabetic } \\
\text { Nephropathy }\end{array}$ & Xu et al. (2016) \\
\hline $\begin{array}{l}\text { Diabetes induced } \\
\text { by STZ }\end{array}$ & In vivo & $\begin{array}{l}\text { eNOS-null male mice } \\
\text { on a C57BL/6 (8 weeks) }\end{array}$ & $\begin{array}{l}\text { Puerarin } 20 \mathrm{mg} / \mathrm{kg} / \mathrm{d} \\
\text { for } 8 \text { weeks }\end{array}$ & $\begin{array}{l}\text { Anti-oxidative } \\
\text { stress; Anti- } \\
\text { inflammatory }\end{array}$ & $\begin{array}{l}\text { SIRT1-NF-кB pathway } \\
\text { (SIRT1) }\end{array}$ & $\begin{array}{l}\text { Diabetic } \\
\text { Nephropathy }\end{array}$ & Li et al. (2017) \\
\hline Normal glucose & In vitro & Murine podocytes & Puerarin for $24 \mathrm{~h}$ & $\begin{array}{l}\text { Anti-oxidative } \\
\text { stress; Anti- } \\
\text { inflammatory }\end{array}$ & $\begin{array}{l}\text { SIRT1-NF-кB pathway } \\
\text { (SIRT1) }\end{array}$ & $\begin{array}{l}\text { Diabetic } \\
\text { Nephropathy }\end{array}$ & Li et al. (2017) \\
\hline $\begin{array}{l}\text { Diabetes induced } \\
\text { by STZ }\end{array}$ & In vivo & $\begin{array}{l}\text { SD rats }(7-8 \text { weeks, } \\
180-220 \mathrm{~g})\end{array}$ & $\begin{array}{l}\text { Puerarin 40, 80, } \\
160 \text { mg/kg/d for } \\
8 \text { weeks (i.p., } n=10 \text { ) }\end{array}$ & Anti-inflammatory & $\begin{array}{l}\text { NF-кB pathway (NF- } \\
\text { kBp65) }\end{array}$ & $\begin{array}{l}\text { Diabetic } \\
\text { Nephropathy }\end{array}$ & $\begin{array}{l}\text { Cui and Wang, } \\
(2010)\end{array}$ \\
\hline $\begin{array}{l}\text { Diabetes induced } \\
\text { by STZ }\end{array}$ & In vivo & $\begin{array}{l}\text { Male SD rats (7 weeks, } \\
200-250 \mathrm{~g})\end{array}$ & $\begin{array}{l}\text { Puerarin } 0.25,0.5 \text {, } \\
1 \mathrm{mg} / \mathrm{kg} / \mathrm{d} \text { for } 8 \text { weeks } \\
\text { (i.g., } \mathrm{n}=10 \text { ) }\end{array}$ & Anti-inflammatory & $\begin{array}{l}\text { Inhibition ICAM-1 and } \\
\text { TNF-a expressions }\end{array}$ & $\begin{array}{l}\text { Diabetic } \\
\text { Nephropathy }\end{array}$ & $\begin{array}{l}\text { Pan et al. } \\
(2015)\end{array}$ \\
\hline $\begin{array}{l}\text { Diabetes induced } \\
\text { by STZ }\end{array}$ & In vivo & $\begin{array}{l}\text { Male Wistar rats } \\
(210-230 \mathrm{~g})\end{array}$ & $\begin{array}{l}\text { Puerarin 140, } \\
200 \mathrm{mg} / \mathrm{kg} / \mathrm{d} \text { for } \\
30 \text { days (p.o., } \mathrm{n}=10 \text { ) }\end{array}$ & Anti-inflammatory & $\begin{array}{l}\text { TGF- } \beta 1 / \text { Smad } 2 \text { signal } \\
\text { pathway (TGF- } \beta 1)\end{array}$ & $\begin{array}{l}\text { Diabetic } \\
\text { Nephropathy }\end{array}$ & $\begin{array}{l}\text { She et al. } \\
(2014)\end{array}$ \\
\hline High-fat diet (HFD) & In vivo & $\begin{array}{l}\text { KKAy male mice (9-11 } \\
\text { weeks, 25-28 g) }\end{array}$ & $\begin{array}{l}\text { Puerarin } 1.3 \mathrm{mg} / \mathrm{kg} / \mathrm{d} \\
\text { for } 24 \text { weeks }(\mathrm{n}=8)\end{array}$ & Anti-inflammatory & $\begin{array}{l}\text { Inhibit TGF- } \beta 1 \text { and } \\
\text { TGF- } \beta \text { RI } \\
\text { expressions ( } \alpha-S M A)\end{array}$ & $\begin{array}{l}\text { Diabetic } \\
\text { Nephropathy }\end{array}$ & Yi et al. (2013) \\
\hline $\begin{array}{l}\text { Diabetes induced } \\
\text { by STZ }\end{array}$ & In vivo & $\begin{array}{l}\text { Male SD rats (8 weeks, } \\
180-220 \mathrm{~g})\end{array}$ & $\begin{array}{l}\text { Puerarin 20, 40, } \\
80 \mathrm{mg} / \mathrm{kg} \text { for } 8 \text { weeks } \\
\text { (i.g., } \mathrm{n}=9 \text { ) }\end{array}$ & Anti-inflammatory & $\begin{array}{l}\text { TLR4/MyD88/NF- } \\
\text { kBp65 pathway } \\
\text { (miRNA-140-5P) }\end{array}$ & $\begin{array}{l}\text { Diabetic } \\
\text { Nephropathy }\end{array}$ & $\begin{array}{l}\text { Xu X et al. } \\
(2020)\end{array}$ \\
\hline DMEM-F12 & In vitro & $\mathrm{HK}-2$ & $\begin{array}{l}\text { Puerarin } 80 \mathrm{mg} / \mathrm{LSP} \\
\text { for } 48 \mathrm{~h}\end{array}$ & Anti-inflammatory & $\begin{array}{l}\text { TLR4/MyD88/NF- } \\
\text { kBp65 pathway } \\
\text { (miRNA-140-5P) }\end{array}$ & $\begin{array}{l}\text { Diabetic } \\
\text { Nephropathy }\end{array}$ & $\begin{array}{l}\text { Xu X et al. } \\
(2020)\end{array}$ \\
\hline $\begin{array}{l}\text { Diabetes induced } \\
\text { by STZ }\end{array}$ & In vivo & $\begin{array}{l}\text { C57BL/6 mouse (8 } \\
\text { weeks, 18-22 g) }\end{array}$ & $\begin{array}{l}\text { Puerarin } 40 \text {, } \\
80 \mathrm{mg} / \mathrm{kg} / \mathrm{d} \text { for } \\
8 \text { weeks (p.o., } \mathrm{n}=10 \text { ) }\end{array}$ & $\begin{array}{l}\text { Promoted } \\
\text { autophagy }\end{array}$ & $\begin{array}{l}\text { PERK/elF2 } \alpha / \text { ATF4 } \\
\text { signaling pathway } \\
\text { (PERP) }\end{array}$ & $\begin{array}{l}\text { Diabetic } \\
\text { Nephropathy }\end{array}$ & $\begin{array}{l}\text { Xu Y et al. } \\
(2020)\end{array}$ \\
\hline $\begin{array}{l}\text { Diabetes induced } \\
\text { by STZ }\end{array}$ & In vivo & $\begin{array}{l}\text { Male C57BL/6 mice (8 } \\
\text { weeks) }\end{array}$ & $\begin{array}{l}\text { Puerarin } 5,10,20 \text {, } \\
40 \mathrm{mg} / \mathrm{kg} \text { for } \\
12 \text { weeks }(\mathrm{n}=8)\end{array}$ & $\begin{array}{l}\text { Promoted } \\
\text { autophagy }\end{array}$ & $\begin{array}{l}\text { AMPK/SIRT1 pathway } \\
\text { (SIRT1) }\end{array}$ & $\begin{array}{l}\text { Diabetic } \\
\text { Nephropathy }\end{array}$ & Li et al. (2020) \\
\hline HG; DMEM & In vitro & $\begin{array}{l}\text { Immortalized mouse } \\
\text { podocytes }\end{array}$ & Puerarin 15 min & $\begin{array}{l}\text { Promoted } \\
\text { autophagy }\end{array}$ & $\begin{array}{l}\text { AMPK/SIRT1 pathway } \\
\text { (SIRT1) }\end{array}$ & $\begin{array}{l}\text { Diabetic } \\
\text { Nephropathy }\end{array}$ & Li et al. (2020) \\
\hline $\begin{array}{l}\text { Diabetes induced } \\
\text { by STZ }\end{array}$ & In vivo & $\begin{array}{l}\text { Male SD rats } \\
(200-250 \mathrm{~g})\end{array}$ & $\begin{array}{l}\text { Puerarin } 100 \mathrm{mg} / \mathrm{kg} / \mathrm{d} \\
\text { for } 8 \text { weeks (i.p., } \mathrm{n} \\
=11 \text { ) }\end{array}$ & $\begin{array}{l}\text { Inhibit AGEs } \\
\text { formation }\end{array}$ & Inhibit AGEs formation & $\begin{array}{l}\text { Diabetic } \\
\text { Nephropathy }\end{array}$ & $\begin{array}{l}\text { Shen et al. } \\
\text { (2009) }\end{array}$ \\
\hline $\begin{array}{l}\text { Diabetes induced } \\
\text { by STZ }\end{array}$ & In vivo & $\begin{array}{l}\text { Male SD rats } \\
(180-200 \mathrm{~g})\end{array}$ & $\begin{array}{l}\text { Puerarin } 100 \mathrm{mg} / \mathrm{kg} / \mathrm{d} \\
\text { for } 4 \text { weeks (i.p., } \mathrm{n} \\
=10 \text { ) }\end{array}$ & $\begin{array}{l}\text { Anti-oxidative } \\
\text { stress }\end{array}$ & $\begin{array}{l}\text { Inhibit eNOS } \\
\text { expressions }\end{array}$ & $\begin{array}{l}\text { Diabetic } \\
\text { Nephropathy }\end{array}$ & $\begin{array}{l}\text { Zhang et al. } \\
\text { (2015) }\end{array}$ \\
\hline$H G$ & In vitro & mMVEC & $\begin{array}{l}\text { Puerarin } 5,10,20 \mu \mathrm{M} \\
+\mathrm{HG} \text { for } 24 \mathrm{~h}\end{array}$ & Anti-inflammatory & NF-кB pathway (NF-kB) & $\begin{array}{l}\text { Diabetic } \\
\text { Macroangiopathy }\end{array}$ & $\begin{array}{l}\text { Lian et al. } \\
\text { (2019) }\end{array}$ \\
\hline $\begin{array}{l}\text { Diabetes induced } \\
\text { by STZ }\end{array}$ & In vivo & $\begin{array}{l}\text { Male SD rats } \\
(250-280 \mathrm{~g})\end{array}$ & $\begin{array}{l}\text { Puerarin 15, } \\
45 \mathrm{mg} / \mathrm{kg} / \mathrm{d} \text { for } \\
3 \text { weeks (i.p., } \mathrm{n}=8 \text { ) }\end{array}$ & Anti-inflammatory & $\begin{array}{l}\text { NF-кB pathway (NF- } \\
\text { kBp65) }\end{array}$ & $\begin{array}{l}\text { Diabetic } \\
\text { Macroangiopathy }\end{array}$ & Li et al. (2016) \\
\hline L-DMEM & In vitro & HUVECs & $\begin{array}{l}\text { Puerarin 1, 10, } 50 \mu \mathrm{M} \\
\text { for } 8 \mathrm{~h}\end{array}$ & Anti-inflammatory & $\begin{array}{l}\text { IKKb/NF-kB pathway } \\
\text { (NF-kBp65); IKKb/IRS- } \\
1 \text { pathway }\end{array}$ & $\begin{array}{l}\text { Diabetic } \\
\text { Macroangiopathy }\end{array}$ & $\begin{array}{l}\text { Huang et al. } \\
(2012)\end{array}$ \\
\hline DMSO & In vitro & EA.hy926 cells & $\begin{array}{l}\text { Puerarin } 100 \mu \mathrm{M} \\
\text { for } 1 \mathrm{~h}\end{array}$ & $\begin{array}{l}\text { Anti-oxidative } \\
\text { stress }\end{array}$ & $\begin{array}{l}\text { PI3K/Akt and CaMKII/ } \\
\text { AMPK pathway (IRS-1) }\end{array}$ & $\begin{array}{l}\text { Diabetic } \\
\text { Macroangiopathy }\end{array}$ & $\begin{array}{l}\text { Hwang et al. } \\
\text { (2011) }\end{array}$ \\
\hline FBS & In vitro & Rat VSMCs & $\begin{array}{l}\text { Puerarin 10-100 } \mu \mathrm{M} \\
\text { for } 1 \mathrm{~h}\end{array}$ & $\begin{array}{l}\text { Anti-oxidative } \\
\text { stress }\end{array}$ & $\begin{array}{l}\text { PKC } 32 / \text { Rac1 pathway } \\
\text { (Rac1) }\end{array}$ & $\begin{array}{l}\text { Diabetic } \\
\text { Macroangiopathy }\end{array}$ & $\begin{array}{l}\text { Zhu et al. } \\
(2010)\end{array}$ \\
\hline $\begin{array}{l}\text { Diabetes induced } \\
\text { by STZ }\end{array}$ & In vivo & $\begin{array}{l}\text { Male SD rats }(8-10 \\
\text { weeks, } 180-220 \mathrm{~g})\end{array}$ & $\begin{array}{l}\text { Puerarin } 80 \mathrm{mg} / \mathrm{kg} / \mathrm{d} \\
\text { for } 12 \text { weeks (i.g., } \mathrm{n} \\
=25 \text { ) }\end{array}$ & $\begin{array}{l}\text { Inhibit AGEs } \\
\text { formation }\end{array}$ & Inhibit AGEs formation & $\begin{array}{l}\text { Diabetic } \\
\text { Retinopathy }\end{array}$ & Liu et al. (2018) \\
\hline $\begin{array}{l}\text { Diabetes induced } \\
\text { by STZ }\end{array}$ & In vivo & $\begin{array}{l}\text { SD rats }(8-10 \text { weeks, } \\
200-220 \mathrm{~g})\end{array}$ & $\begin{array}{l}\text { Puerarin 250, } \\
500 \mathrm{mg} / \mathrm{kg} \text { (i.v., n } \\
=10 \text { ) }\end{array}$ & Anti-inflammatory & JAK2/STAT3 pathway & $\begin{array}{l}\text { Diabetic } \\
\text { Retinopathy }\end{array}$ & Cai et al. (2017) \\
\hline $\begin{array}{l}\text { Diabetes induced } \\
\text { by STZ }\end{array}$ & In vivo & $\begin{array}{l}\text { Male Wistar rats }(6-8 \\
\text { weeks, } 180-220 \mathrm{~g})\end{array}$ & $\begin{array}{l}\text { Puerarin 25, 50, } \\
100 \text { mg/kg for } \\
12 \text { weeks (i.p., } n=18 \text { ) }\end{array}$ & Anti-inflammatory & Nrf2/HO-1 pathway & $\begin{array}{l}\text { Diabetic } \\
\text { Retinopathy }\end{array}$ & $\begin{array}{l}\text { Zhang and Li, } \\
\text { (2019) }\end{array}$ \\
\hline
\end{tabular}


TABLE 5 | (Continued) The protective mechanism of Puerarin against diabetic complications.

\begin{tabular}{|c|c|c|c|c|c|c|c|}
\hline Model & Assay & Species & Dose & $\begin{array}{l}\text { Protective } \\
\text { mechanism }\end{array}$ & $\begin{array}{c}\text { Pathways (Target } \\
\text { cells) }\end{array}$ & $\begin{array}{l}\text { Diabetes } \\
\text { complications }\end{array}$ & References \\
\hline $\begin{array}{l}\text { Diabetes induced } \\
\text { by STZ }\end{array}$ & In vivo & Wistar rats $(280-320 \mathrm{~g})$ & $\begin{array}{l}\text { Puerarin } 100 \mathrm{mg} / \mathrm{kg} \\
\text { for } 6 \text { weeks (i.p., } \mathrm{n} \\
=20 \text { ) }\end{array}$ & Anti-inflammatory & Nrf2/ERK pathway & $\begin{array}{l}\text { Diabetic } \\
\text { Retinopathy }\end{array}$ & $\begin{array}{l}\text { Zhang and } \\
\text { Wang, (2019) }\end{array}$ \\
\hline $\begin{array}{l}\text { Diabetes induced } \\
\text { by STZ }\end{array}$ & In vivo & $\begin{array}{l}\text { Male SD mice (5-6 } \\
\text { weeks, 200-220 g) }\end{array}$ & $\begin{array}{l}\text { Puerarin } 140 \text { mg/kg } \\
\text { for } 56 \text { days (i.p., n } \\
=36 \text { ) }\end{array}$ & Anti-apoptosis & $\begin{array}{l}\text { Fas/FasL pathway } \\
\text { (ONOO-) }\end{array}$ & $\begin{array}{l}\text { Diabetic } \\
\text { Retinopathy }\end{array}$ & $\begin{array}{l}\text { Hao et al. } \\
(2012)\end{array}$ \\
\hline $\begin{array}{l}\text { Diabetes induced } \\
\text { by STZ }\end{array}$ & In vivo & Male SD rats (250 g) & $\begin{array}{l}\text { Puerarin } 140 \text { mg/kg } \\
\text { for } 56 \text { days (i.p., n } \\
=12 \text { ) }\end{array}$ & Anti-apoptosis & $\begin{array}{l}\text { Inhibit ONOO- } \\
\text { expression }\end{array}$ & $\begin{array}{l}\text { Diabetic } \\
\text { Retinopathy }\end{array}$ & $\begin{array}{l}\text { Hao et al. } \\
(2010)\end{array}$ \\
\hline ONOO- & In vitro & $\begin{array}{l}\text { C57BL/6 mice RPE } \\
\text { (Passage 2-3) }\end{array}$ & Puerarin for $24 \mathrm{~h}$ & Anti-apoptosis & $\begin{array}{l}\text { Inhibit ONOO- } \\
\text { expression }\end{array}$ & $\begin{array}{l}\text { Diabetic } \\
\text { Retinopathy }\end{array}$ & $\begin{array}{l}\text { Hao et al. } \\
(2010)\end{array}$ \\
\hline $\begin{array}{l}\text { Diabetes induced } \\
\text { by STZ + HG + } \\
\text { High-fat diet (HFD) }\end{array}$ & In vivo & $\begin{array}{l}\text { Male SD rats } \\
(120-160 \mathrm{~g})\end{array}$ & $\begin{array}{l}\text { Puerarin } 0.56 \text {, } \\
2.81 \mathrm{~g} / \mathrm{kg} \text { for } \\
4 \text { weeks (i.g.) }\end{array}$ & $\begin{array}{l}\text { Inhibit AGEs } \\
\text { formation }\end{array}$ & Inhibit AGEs formation & $\begin{array}{l}\text { Diabetic } \\
\text { Retinopathy }\end{array}$ & $\begin{array}{l}\text { Deng et al. } \\
(2021)\end{array}$ \\
\hline Nembutal & In vivo & SD rats (300-340 g) & $\begin{array}{l}\text { Puerarin } 40 \text { mg/kg for } \\
72 \text { h (i.p., } n=5 \text { ) }\end{array}$ & Anti-inflammatory & $\begin{array}{l}\text { Inhibit ICAM-1 } \\
\text { expression }\end{array}$ & $\begin{array}{l}\text { Diabetic } \\
\text { Retinopathy }\end{array}$ & Li, (2007) \\
\hline $\begin{array}{l}\text { Diabetes induced } \\
\text { by STZ }\end{array}$ & In vivo & $\begin{array}{l}\text { Male Wistar rats } \\
(240-260 \mathrm{~g})\end{array}$ & $\begin{array}{l}\text { Puerarin 2, } 5 \text { mg/kg } \\
\text { for } 12 \text { weeks (i.g., } n \\
=20 \text { ) }\end{array}$ & Anti-inflammatory & $\begin{array}{l}\text { IGF- } 1 \text { and TNF- } \alpha \\
\text { expressions }\end{array}$ & $\begin{array}{l}\text { Diabetic } \\
\text { Retinopathy }\end{array}$ & $\begin{array}{l}\text { Yang et al. } \\
(2016 b)\end{array}$ \\
\hline $\begin{array}{l}\text { Diabetes induced } \\
\text { by STZ }\end{array}$ & In vivo & Male mice (200-220 g) & $\begin{array}{l}\text { Puerarin 50, } \\
100 \mathrm{mg} / \mathrm{kg} / \mathrm{d} \text { for } \\
8 \text { weeks }(\mathrm{n}=10)\end{array}$ & Anti-apoptosis & $\begin{array}{l}\text { Increase } \mathrm{Bcl}-2 \\
\text { expression (Bcl-2) }\end{array}$ & $\begin{array}{l}\text { Diabetic } \\
\text { Cardiomyopathy }\end{array}$ & $\begin{array}{l}\text { Ling et al. } \\
\text { (2011) }\end{array}$ \\
\hline $\begin{array}{l}\text { Diabetes induced } \\
\text { by STZ }\end{array}$ & In vivo & $\begin{array}{l}\text { Male SD rats } \\
(180-240 \mathrm{~g})\end{array}$ & $\begin{array}{l}\text { Puerarin } 100 \mathrm{mg} / \mathrm{kg} / \mathrm{d} \\
\text { for } 8 \text { weeks (i.p., } \mathrm{n} \\
=11 \text { ) }\end{array}$ & $\begin{array}{l}\text { Inhibit AGEs } \\
\text { formation }\end{array}$ & Inhibit AGEs formation & $\begin{array}{l}\text { Diabetic } \\
\text { Cardiomyopathy }\end{array}$ & Ye et al. (2013) \\
\hline $\begin{array}{l}\text { Diabetes induced } \\
\text { by STZ }\end{array}$ & In vivo & $\begin{array}{l}\text { Male SD rats } \\
(200-300 \mathrm{~g})\end{array}$ & $\begin{array}{l}\text { Puerarin 40, 80, } \\
160 \text { mg/kg/d for } \\
12 \text { weeks (i.g., } n=10 \text { ) }\end{array}$ & $\begin{array}{l}\text { Inhibit RAS } \\
\text { System }\end{array}$ & $\begin{array}{l}\text { Inhibit RAS System } \\
\text { (Ang-II) }\end{array}$ & $\begin{array}{l}\text { Diabetic } \\
\text { Cardiomyopathy }\end{array}$ & $\begin{array}{l}\text { Gao et al. } \\
(2017)\end{array}$ \\
\hline$I H G$ & In vitro & $\begin{array}{l}\text { SCs from the sciatic } \\
\text { nerves of neonatal SD } \\
\text { rats }\end{array}$ & $\begin{array}{l}\text { Puerarin } 10,25,50 \\
\text { Imol/I for } 48 \mathrm{~h}\end{array}$ & Anti-apoptosis & Inhibit ROS production & $\begin{array}{l}\text { Diabetic Peripheral } \\
\text { Neuropathy }\end{array}$ & $\begin{array}{l}\text { Chen et al. } \\
\text { (2013) }\end{array}$ \\
\hline $\begin{array}{l}\text { Diabetes induced } \\
\text { by STZ }\end{array}$ & In vivo & $\begin{array}{l}\text { Male SD rats (6 weeks, } \\
180-220 \mathrm{~g})\end{array}$ & $\begin{array}{l}\text { Puerarin 80, 160, } \\
120 \text { mg/kg for } \\
12 \text { weeks (i.p.) }\end{array}$ & Anti-inflammatory & MAPK pathway (NO) & $\begin{array}{l}\text { Diabetic Peripheral } \\
\text { Neuropathy }\end{array}$ & $\begin{array}{l}\text { Zhao et al. } \\
(2008)\end{array}$ \\
\hline $\begin{array}{l}\text { Diabetes induced } \\
\text { by STZ/CCl }\end{array}$ & In vivo & $\begin{array}{l}\text { Male SD rats } \\
(220-250 \mathrm{~g}) / \mathrm{CCl}\end{array}$ & $\begin{array}{l}\text { Puerarin } 4,20 \\
100 \mathrm{nM} \text { for } 7 \text { days }\end{array}$ & Anti-inflammatory & NF-кB pathway (NF-kB) & $\begin{array}{l}\text { Diabetic Peripheral } \\
\text { Neuropathy }\end{array}$ & $\begin{array}{l}\text { Xue et al. } \\
(2017)\end{array}$ \\
\hline $\begin{array}{l}\text { Diabetes induced } \\
\text { by STZ }\end{array}$ & In vivo & $\begin{array}{l}\text { SD rats (12 weeks, } \\
107.2-131.88 \mathrm{~g})\end{array}$ & $\begin{array}{l}\text { Puerarin } 10,20 \text {, } \\
40 \text { mg/kg for } \\
20 \text { weeks (i.g., } n=20 \text { ) }\end{array}$ & Anti-inflammatory & PI3K/Akt pathway & Cognitive Disorders & $\begin{array}{l}\text { Chen et al. } \\
\text { (2010b) }\end{array}$ \\
\hline $\begin{array}{l}\text { Diabetes induced } \\
\text { by STZ }\end{array}$ & In vivo & $\begin{array}{l}\text { Male Wistar rats } \\
(210-230 \mathrm{~g})\end{array}$ & $\begin{array}{l}\text { Puerarin } 100 \mathrm{mg} / \mathrm{kg} / \mathrm{d} \\
\text { for } 7 \text { days (p.o., } \mathrm{n} \\
=20 \text { ) }\end{array}$ & $\begin{array}{l}\text { Anti-oxidative } \\
\text { stress; Anti- } \\
\text { inflammatory }\end{array}$ & NF-кB pathway (NF-kB) & Cognitive Disorders & $\begin{array}{l}\text { Liu J et al. } \\
\text { (2014) }\end{array}$ \\
\hline $\begin{array}{l}\text { Diabetes induced } \\
\text { by STZ }\end{array}$ & In vivo & $\begin{array}{l}\text { Female C57 mice ( } 3 \\
\text { months, } 18-22 \mathrm{~g})\end{array}$ & $\begin{array}{l}\text { Puerarin 25, 50, } \\
100 \text { mg/kg/d for } \\
4 \text { weeks (icv., i.g.) }\end{array}$ & $\begin{array}{l}\text { Anti-oxidative } \\
\text { stress }\end{array}$ & $\begin{array}{l}\text { Anti-oxidative stress } \\
\text { response }\end{array}$ & Cognitive Disorders & $\begin{array}{l}\text { Hao et al. } \\
(2019)\end{array}$ \\
\hline
\end{tabular}

Smad2 signal pathway results in the kidney's extracellular matrix (ECM) accumulation. Therefore Puerarin exerted its antidiabetic effect by inhibiting the TGF- $\beta 1 / \mathrm{Smad} 2$ signaling pathway and reducing the accumulation of extracellular matrix in the kidney (She et al., 2014). In addition, Puerarin could restrain the protein expressions of TGF- $\beta 1$ and TGF- $\beta 1$ receptors (TGF- $\beta$-RI) in the kidney tissue of KKAy mice via reducing the expression of $\alpha$-smooth muscle actin ( $\alpha$-SMA) (Yi et al., 2013). It also inhibited the TLR4/MyD88/NF-kBp65 pathway by upregulating miRNA-140-5p, thus reducing expression levels of TNF- $\alpha$, interleukin-1 $\beta$ (IL-1 $\beta$ ), interleukin-6 (IL-6), interferon- $\gamma$ (INF- $\gamma$ ), and TGF- $\beta 1$ in renal tissues of diabetic rats (Xu X et al., 2020). These changes may inhibit and reverse the epithelialmesenchymal transition process, thus delaying the occurrence, preventing diabetes-induced renal damage and the development of DN.

Moreover, Puerarin can promote autophagy mechanisms through the following two signaling pathways. Puerarin modulated ERS/autophagy crosstalk by regulating activated extracellular signal-regulated kinase ( $p$-ERK), persistent ERS activated the $p$-ERK-eukaryotic translation initiation factor $2 \alpha$ (eIF2 $\alpha$ ) signaling pathway, activating transcription factor 4 (ATF4) is then up-regulated in response to eIF2 $\alpha$ phosphorylation. CHOP and Beclin-1 were activated through regulating of the PERK/eIF2a/ATF4 signaling pathway, upregulated the levels of autophagy markers Beclin-1, microtubule-associated protein light chain 3 II (LC3II), and autophagy-related 5 homolog (Atg5), and down-regulated the 
level of p62, thus resulted in the autophagy response (Xu Y et al., 2020). It also protected against podocyte injury by restoring the autophagic activity via the AMPK/SIRT1 pathway. In vitro and in vivo experiments demonstrate, Puerarin stimulated SIRT1 expression in podocytes to deacetylate liver kinase B1 (LKB1) and then phosphorylated AMPK-mTOR pathway to induce autophagy (Li et al., 2020).

Advanced glycation end products (AGEs) and RAGE play an essential role in developing diabetic nephropathy. Puerarin could protect the renal tissue from the impairment of hyperglycemia and AGE by decreasing AGEs contents and inhibiting the expression of RAGE mRNA in the kidney, which may due to decrease blood glucose directly, or reduce AGEs formation by inhibiting oxidative stress, aldose reductase activity, and, so on (Shen et al., 2009). Furthermore, Puerarin also attenuates eNOS expression in glomerular endothelial cells (Zhang et al., 2015).

Together, Puerarin can achieve inhibitory non-enzymatic glycosylation of the protein, alleviate oxidative stress or inflammatory response damage, and promote autophagy response through the above pathways, thus protecting diabetes-induced kidney damage and delaying the occurrence and development of DN.

\section{Diabetic Macroangiopathy}

Hyperglycemia could cause a non-classic inflammation response in the vascular endothelium and contributes to the inflammation response through the aggregation of intracellular ROS (Lian et al., 2019). So there is a correlation between DM and the occurrence of oxidative stress products and inflammatory factors in a highglucose environment. Puerarin inhibits the occurrence of oxidative stress and inflammatory response mainly through the following signaling pathways.

ROS in vascular the primary source is the NADPH oxidase (NOX family). ROS is a critical upstream activator of the NF$\mathrm{kB}$ pathway (Li et al., 2016), which consequently increases the expressions of lectin-like oxidized low-density lipoprotein receptor-1 (LOX-1), ICAM-1, and E-selectin, and Nlrp3 inflammasome activation (Li et al., 2016). High mobility group box 1 (HMGB1) release is a downstream product of Nlrp3 inflammasome activation (Lian et al., 2019). Thus, NF-kB, the critical transcription factor in regulating molecular adhesion expression, plays an essential role in DM. Puerarin inhibited NADPH oxidase 2 (NOX2) and NOX4 expressions in vascular smooth muscle cells (VSMCs) through regulating NF-kBp65 to suppress oxidative stress and expressions of cell adhesion molecules (Li et al., 2016). It also attenuated IKKb phosphorylation and effectively blocked NF-kB activation by inhibiting NF-kBp65 phosphorylation and decreased TNF- $\alpha$ and IL- 6 production by inhibiting IKKb/NF-kB activation (Huang et al., 2012). In addition, this is a new protection mechanism of Puerarin that inhibited NF-kB activation by suppressing oxidative stress, subsequently inhibited Nlrp3 inflammasome activation, attenuated TXNIP-NLRP3 binding, decreased subsequent Caspase-1 activation, and decreased the release of HMGB1 (Lian et al., 2019).
Moreover, Puerarin also stimulated endothelial nitric oxide synthase (eNOS) phosphorylation and nitric oxide (NO) production via activation of an estrogen receptor-mediated PI3K/Akt and CaMKII/AMPK dependent pathway. It attenuated phosphorylation of IRS-1 at S307 and effectively ameliorated the tyrosine phosphorylation of IRS-1, which activated PI3K, subsequently activated PI3K phosphorylates and activated downstream target Akt which directly phosphorylated eNOS at Ser1177, leading to increased production of NO(Hwang et al., 2011). (Figure 3)

In vitro, Puerarin disrupted the phosphorylation and membrane translocation of PKC $\beta 2$ as well as Rac1, p47phox, and p67phox subunits and NADPH oxidase activation in VSMCs may exert inhibitory effects on high-glucose-induced VSMC proliferation via interfering with PKC $\beta 2 / \mathrm{Racl}$-dependent ROS pathways (Zhu et al., 2010).

In summary, Puerarin inhibited inflammatory response and oxidative stress via inhibiting NF-kB activation, and it inhibited oxidative stress via ameliorating PI3K/Akt, CaMKII/AMPK, and PKC $32 /$ Rac1 pathway. Accordingly, Puerarin ameliorated IRassociated endothelial dysfunction.

\section{Diabetic Retinopathy}

$\mathrm{DR}$ is an alteration of diabetic microangiopathy in the specific environment of the fundus. Long-term chronic hyperglycemia causes oxidative stress, inflammatory response, and nonenzymatic glycosylation of proteins, which promotes apoptosis and accelerates the onset of DR. Puerarin protects retinal function through the following pathways.

In response to high glucose toxicity, the activity of ROS is increased, causing phosphorylation of retinal capillary endothelial cells in JAK2/STAT3, thereby increasing the expression of vascular endothelial growth factor (VEGF). Thus, the mechanism of the Puerarin effect is hypothesized to be due to inhibition of the phosphorylation of JAK2/STAT3, thereby reducing the expression of VEGF and the inflammation of the retina, and that results in preventing the occurrence of DR (Cai et al., 2017). Furthermore, Puerarin decreased the expression levels of retinal vascular endothelial growth factor (VEGF) and IL-1 $\beta$ through activating nuclear factor-E2 related factor2 (Nrf2)/ HO-1 signaling pathway (Zhang and Li, 2019) and inhibiting the Nrf2/ERK signaling pathway (Zhang and Wang, 2019), thus, reduced the inflammatory response and inhibiting oxidative stress of retinal tissue.

The Fas/FasL system is considered the primary signal transduction pathway to mediate apoptosis, and it may affect and strengthen the apoptosis process mediated by ONOO- (Hao et al., 2010; Hao et al., 2012). Thus, Puerarin could protect retinal pigment epithelial cells (RPE) of diabetic rats through inhibiting inducible nitric oxide synthase (iNOS) up-regulation and ONOO-generation mediated through Fas/FasL signal pathway (Hao et al., 2010; Hao et al., 2012).

The prolonged hyperglycemic state can induce the production of AGEs. Puerarin inhibited the productions of AGEs-modified proteins and their accumulation in the retina by inhibiting the non-enzymatic glycosylation of proteins to improve DR. Components of flavonoid structures can capture 
dicarbonyl compounds (key intermediates in AGEs formation) and form adducts, thus exerting an inhibitory effect on AGEs formation, and it is speculated that the mechanism of action of total flavonoid extracts of Pueraria to inhibit AGEs levels may be related to this (Liu et al., 2018; Deng et al., 2021).

In addition, Puerarin raised the expression of insulin-like growth factor-1 (IGF-1) and decreased the expressions of TNF$\alpha$, ICAM-1, IL-1 $\beta$, and IL- 6 in the retina to protect the function of the retina (Li, 2007; Yang et al., 2016b; Deng et al., 2021).

In conclusion, Puerarin could protect RPE cells and the function of the retina by reducing the inflammatory response, inhibiting oxidative stress and apoptosis of retinal tissue, inhibiting nonenzymatic glycosylation reactions of the proteins.

\section{Diabetic Cardiomyopathy}

Chronic hyperglycemic environments promote oxidative stress and the release of inflammatory factors through processes such as glycosylation, thus damaging the myocardium. Puerarin may reduce myocardial damage through the following pathways.

On the one hand, Puerarin increased Bcl-2 expression in the myocardium, afterward suppressed permeabilization of the mitochondrial inner membrane to Cyt-C, subsequently reduced the release of $\mathrm{Cyt}-\mathrm{C}$, inhibited the formation of apoptotic bodies, subsequently regulated activation of the Caspase-3, are suggested to be the mechanisms responsible for puerarin's anti-apoptotic effect against diabetic cardiomyopathy in STZ induced SD rats (Ling et al., 2011). (Figure 2)

Moreover, it also reduced RAGE expression at the mRNA level by reducing blood sugar, subsequently reduced AGE-RAGE binding, reduced the myocardial oxidative stress and the inflammatory response. Thus injury was relieved by AGEs in diabetic rats (Ye et al., 2013).

For another, AT1R mediates almost all cardiovascular effects of angiotensin-II (Ang-II). Puerarin decreased myocardial AT1R protein expression and reduced cardiac Ang-II levels in diabetic rats. On the one hand, it inhibited renin-angiotensin system (RAS) activation and suppressed cardiomyocyte hypertrophy and fibrosis, thus improving cardiac systolic and diastolic functions. On the one hand, it inhibited TNF- $\alpha$ and IL- $1 \beta$ expressions, suppressed Caspase-9 activation, inhibited inflammatory factor release and cardiomyocyte apoptosis, thereby protecting the myocardium. In addition, Puerarin could improve IR by decreasing Ang-II levels (Zhao et al., 2008; Chen et al., 2013; Gao et al., 2017).

\section{Diabetic Peripheral Neuropathy}

DPN is one of the most prevalent and debilitating microvascular complications of diabetes, affecting at least $50 \%$ of people with diabetes (Xue et al., 2017). Schwann cells (SCs) are the most critical myelinating cells of the peripheral nervous system. Hyperglycemia-induced abnormalities of SCs could cause a cause of demyelination of nerve fibers, reduction of regeneration capability in peripheral nerves, and axonal atrophy, resulting in the development of DPN(Xue et al., 2017). Therefore, to SCs, Puerarin significantly inhibited glucose fluctuation-stimulated ROS production and mitochondrial depolarization in SCs, subsequently suppressed mitochondrial dysfunction, down-regulated the expression of proapoptotic factors (e.g., Bax), and upregulated the expression of anti-apoptotic factors (e.g., Bcl2 ), which subsequently suppressed Caspase-3 activation and PARP cleavage in SCs, thus inhibited SCs apoptosis (Xue et al., 2017). In addition, Puerarin activated T-type Ca2+ channel and mitogen-activated protein kinases (MAPK) signaling by upregulating NO level, which up-regulated the expression of the calcitonin gene-related peptide (CGRP) gene to enhance the antagonistic effect of CGRP on endothelin-1 (ET-1), improved endure blood supply (Chen et al., 2010b). The antiinflammation effect of Puerarin might be related to the suppression of spinal NF-kB activation or cytokines upregulation (Liu M et al., 2014).

Moreover, Puerarin significantly inhibited the proinflammatory response and oxidative stress in the cerebral cortex and hippocampus by activating PI3K/Akt signaling pathway (Hao et al., 2019) and inhibiting NF-kB activation (Liu et al., 2016), which determines its cognitive protection in diabetes (Yang et al., 2015).

\section{RESEARCH CONCLUSION}

Diabetes is a non-communicable metabolic disease characterized by chronic hyperglycemia (Meng et al., 2017; Niu et al., 2017). Severe or persistent hyperglycemia-induced a series of diabetic complications cannot be ameliorated by antidiabetic agents, let alone their adverse side effects, including hypoglycemia, gastrointestinal reactions, liver damage, and lactic acidosis. All these raise concerns over their safety and efficacy in diabetic patients (Srivali et al., 2015). Currently, more proposals of applications of alternative treatment for diabetes and its complications to counteract these side effects have been put forward, of which RP, the most frequently and long-term used TCM, has become a hotspot. The pharmacological properties of Puerarin, a major active component of RP, have been recently uncovered (Cao et al., 2006). Puerarin has been shown to exert antidiabetic effects of reducing blood glucose and improving diabetes complications in patients (Wong et al., 2011). It has been proven to promote $\beta$-cell neogenesis and inhibit apoptosis, enhance the insulin receptor signaling, boost glucose transport and uptake, and suppress hepatic gluconeogenesis through multiple approaches, including activation of GLP-1R and PI3K/ Akt signalings and inhibition of ROS production and Caspase/ AIF apoptotic pathway in the pancreas, enhancement of GLUT4 delivery and PPAR receptor expression alongside increased fatty acid oxidation in skeletal muscle and adipose tissue, and $\mathrm{PI} 3 \mathrm{~K} / \mathrm{Akt}$ activation in the liver. Thus, insulin secretion is restored to improve IR to lower blood glucose. As for diabetic complications, Puerarin has been proven to significantly delay their occurrence and progression via eliminating excessive nonenzymatic glycosylation, oxidative stress, and inflammatory response and suppressing apoptosis caused by chronic hyperglycemia. 
However, limitations on current diabetic research are apparent, despite significant findings of molecular mechanisms for Puerarin's antidiabetic effects. Most clinical studies in this field merely show the low-to-moderate level of evidence, and large-sample randomized controlled studies are urgently needed to offer convincing conclusions. Besides, the effective dose and safety of Puerarin in each type of diabetic complication have not been determined, which calls for more in-vivo and in-vitro experiments and validation by clinical studies or large-sample cohort studies. Moreover, current studies only ascertain the limited efficacy of Puerarin in the treatment of diabetic patients with complications. Overall, Puerarin is a promising new treatment for diabetes and its complications. Further studies into this topic are warranted.

\section{REFERENCES}

Azmi, S., Petropoulos, I. N., Ferdousi, M., Ponirakis, G., Alam, U., and Malik, R. A. (2019). An Update on the Diagnosis and Treatment of Diabetic Somatic and Autonomic Neuropathy. F1000Res 8, F1000. doi:10.12688/f1000research.17118.1

Cai, C. C., Xu, Y. Y., and Wang, H. X. (2014). The Study of Therapeutic Effect and Mechanism of Puerariae Radix Polysaccharides on Type 2 Diabetes Mellitus Rats. Tianjin J. Tradit Chin. Med. 31 (02), 94-97.

Cai, Y., Zhang, X., Xu, X., and Yu, Y. (2017). Effects of Puerarin on the Retina and STAT3 Expression in Diabetic Rats. Exp. Ther. Med. 14 (6), 5480-5484. doi:10.3892/etm.2017.5203

Cao, L., Zhen-Lun, G. U., and Mao, C. P. (2006). Effects of Puerarin on Insulin Resistance in Diabetic Mice. Chin. Traditional Herbal Drugs. 37 (6), 901-904.

Chen, W. C., Hayakawa, S., Yamamoto, T., Su, H. C., Liu, I. M., and Cheng, J. T. (2004). Mediation of Beta-Endorphin by the Isoflavone Puerarin to Lower Plasma Glucose in Streptozotocin-Induced Diabetic Rats. Planta Med. 70 (2), 113-116. doi:10.1055/s-2004-815486

Chen, X., Wang, L., Fan, S., Song, S., Min, H., Wu, Y., et al. (2018a). Puerarin Acts on the Skeletal Muscle to Improve Insulin Sensitivity in Diabetic Rats Involving $\mu$-opioid Receptor. Eur. J. Pharmacol. 818, 115-123. doi:10.1016/ j.ejphar.2017.10.033

Chen, X., Wang, L., Wu, Y. Z., Song, S. Y., Min, H. Y., Yang, Y., et al. (2018b). Effect of Puerarin in Promoting Fatty Acid Oxidation by Increasing Mitochondrial Oxidative Capacity and Biogenesis in Skeletal Muscle in Diabetic Rats. Nutr. Diabetes. 8 (1), 1-13. doi:10.1038/s41387-017-0009-6

Chen, X. F., Dong, M., and Lei, F. K. (2010a). Antihyperglycemic Effect of Puerarin in Experimental Diabetes Mellitus Rats. J. Chin. Pharm. ences. 45 (16), $1242-1246$.

Chen, X. F., Dong, M., and Lei, F. K. (2010b). Effect of Puerarin on Sciatic Nerve Injury Caused by Diabetes Mellitus. J. Wenzhou Med. Coll. 40 (5), 441-449.

Chen, X. F., Lei, F. K., Dong, M., and Zheng, Q. M. (2017). Effects of Puerarin on Pancreatic $\beta$-cell Injury in Type 2 Diabetes Rats. J. Wenzhou Med. Univ. 47 (12), 859-863.

Chen, X. M., Yang, Y., and Wang, Y. (2013). Effects of Puerarin on Apoptosis and Angiotensin II Type 1 Receptor Protein Expression in Diabetic Rat Cardiomyocytes. China Higher Med. Education 2013 (10), 130-131.

Cheng, W., Wu, P., Du, Y., Wang, Y., Zhou, N., Ge, Y., et al. (2015). Puerarin Improves Cardiac Function Through Regulation of Energy Metabolism in Streptozotocin-Nicotinamide Induced Diabetic Mice After Myocardial Infarction. Biochem. Biophys. Res. Commun. 463 (04), 1108-1114. doi:10.1016/j.bbrc.2015.06.067

Cui, X. L., and Wang, Y. Z. (2010). Effect of Puerarin on the Expression of NFkBp65 and TNF- $\alpha$ in Kidney of Diabetic Rats. Med. J. Chin. People's Liberation Army. 35 (6), 679-682.

Cusi, K., Sanyal, A. J., Zhang, S., Hartman, M. L., Bue-Valleskey, J. M., Hoogwerf, B. J., et al. (2017). Non-Alcoholic Fatty Liver Disease (NAFLD) Prevalence and its Metabolic Associations in Patients With Type 1 Diabetes and Type 2 Diabetes. Diabetes Obes. Metab. 19 (11), 1630-1634. doi:10.1111/dom.12973

\section{AUTHOR CONTRIBUTIONS}

All the authors participated in the collation and analysis of the literature data and the modification of the paper. J-hQ carried out the revision of the manuscript and the production of the figure.

\section{ACKNOWLEDGMENTS}

This study was supported by the Research on the Academic Viewpoints, Unique Diagnostic and Treatment Methods and Major Diseases Prevention and Treatment Experience of Illustrious Senior Traditional Chinese Medicine Practitioners in Western China (Grant No. 2018YFC1704104).

Deng, L. P., Xie, M. J., and Zhu, Z. Y. (2021). Effect of Total Flavonoids From Puerariae Lobatae Radix on Retinopathy in Diabetic Rats. Pharmacol. Clin. Chin. Materia Med. 37 (2), 54-59.

Fletcher, E. L., Phipps, J. A., Ward, M. M., Puthussery, T., and Wilkinson-Berka, J. L. (2007). Neuronal and Glial Cell Abnormality as Predictors of Progression of Diabetic Retinopathy. Curr. Pharm. Des. 13 (26), 2699-2712. doi:10.2174/ 138161207781662920

Gao, J. Y., Yang, Y. Y., and Pan, C. F. (2017). Protective Effect of Puerarin on Myocardium of Diabetic Rats. Chin. J. Coal Industry Med. 20 (6), 707-709.

Hao, H. Z., Wang, A. P., Wang, L., and Sun, H. B. (2019). Protective Effect of Puerarin on Cognitive Dysfunction in Diabetic Rats Based on IRS-1/PI3K/Akt Pathway. China Pharmacist. 22 (7), 1220-1226.

Hao, L. N., Wang, M., Ma, J. L., and Yang, T. (2012). Puerarin Decreases Apoptosis of Retinal Pigment Epithelial Cells in Diabetic Rats by Reducing Peroxynitrite Level and iNOS Expression. Sheng Li Xue Bao. 64 (2), 199-206. doi:10.13294/ j.aps.2012.02.007

Hao, L. N., Zhang, Y. Q., Shen, Y. H., Wang, Z. Y., Wang, Y. H., Zhang, H. F., et al. (2010). Effect of Puerarin on Retinal Pigment Epithelial Cells Apoptosis Induced Partly by Peroxynitrite via Fas/fasl Pathway. Int. J. Ophthalmol. 3 (4), 283-287. doi:10.3980/j.issn.2222-3959.2010.04.01

Hsu, F. L., Liu, I. M., Kuo, D. H., Chen, W. C., Su, H. C., and Cheng, J. T. (2003). Antihyperglycemic Effect of Puerarin in Streptozotocin-Induced Diabetic Rats. J. Nat. Prod. 66 (6), 788-792. doi:10.1021/np0203887

Huang, F., Liu, K., Du, H., Kou, J., and Liu, B. (2012). Puerarin Attenuates Endothelial Insulin Resistance Through Inhibition of Inflammatory Response in an IKK $\beta /$ IRS-1-Dependent Manner. Biochimie. 94 (5), 1143-1150. doi:10.1016/j.biochi.2012.01.018

Huang, X., Zhang, D., and Wang, J. (2018). Chemical Composition and Pharmacological Action of Pueraria Lobata. Jilin J. Chin. Med. 38 (01), 87-89. doi:10.13463/j.cnki.jlzyy.2018.01.025

Hwang, Y. P., Kim, H. G., Hien, T. T., Jeong, M. H., Jeong, T. C., and Jeong, H. G. (2011). Puerarin Activates Endothelial Nitric Oxide Synthase Through Estrogen Receptor-Dependent PI3-Kinase and Calcium-Dependent AMPActivated Protein Kinase. Toxicol. Appl. Pharmacol. 257 (1), 48-58. doi:10.1016/j.taap.2011.08.017

Jiang, L. H. (2004). Present Situation of Development and Prospect Analysis on Pueraria Lobata. For. By-product Speciality China. 6, 59-60.

Kim, J. M., Lee, Y. M., Lee, G. Y., Jang, D. S., Bae, K. H., and Kim, J. S. (2006). Constituents of the Roots of Pueraria Lobata Inhibit Formation of Advanced Glycation End Products (AGEs). Arch. Pharm. Res. 29 (10), 821-825. doi:10.1007/BF02973900

Li, G. H. (2007). Effect of Puerarin on the Expression of ICAM-1 in Rat's IschemiaReperfusion Injury in Retina. China J. Mod. Med. 17 (19), 2334-2340.

Li, J. J., and Bi, H. M. (2004). Effects of Puerarin on GLUT4 in Adipocyte of Rats With Insulin Resistance. Chin. J. Clin. Pharmacol. Ther. 09 (8), 885-888.

Li, W., Zhao, W., Wu, Q., Lu, Y., Shi, J., and Chen, X. (2016). Puerarin Improves Diabetic Aorta Injury by Inhibiting NADPH Oxidase-Derived Oxidative Stress in STZ-Induced Diabetic Rats. J. Diabetes Res. 2016, 1-9. doi:10.1155/2016/ 8541520 
Li, X., Zhu, Q., Zheng, R., Yan, J., Wei, M., Fan, Y., et al. (2020). Puerarin Attenuates Diabetic Nephropathy by Promoting Autophagy in Podocytes. Front. Physiol. 11, 73. doi:10.3389/fphys.2020.00073

Li, X. L., Cai, W. J., and Lee, K. (2017). Puerarin Attenuates Diabetic Kidney Injury Through the Suppression of NOX4 Expression in Podocytes. Scientific Rep. 7 (1), 905-906. doi:10.1038/s41598-017-14906-8

Li, Z., Shangguan, Z., Liu, Y., Wang, J., Li, X., Yang, S., et al. (2014). Puerarin Protects Pancreatic $\beta$-Cell Survival via PI3K/Akt Signaling Pathway. J. Mol. Endocrinol. 53 (1), 71-79. doi:10.1530/JME-13-0302

Lian, D., Yuan, H., Yin, X., Wu, Y., He, R., Huang, Y., et al. (2019). Puerarin Inhibits Hyperglycemia-Induced Inter-Endothelial Junction Through Suppressing Endothelial Nlrp3 Inflammasome Activation via ROS-dependent Oxidative Pathway. Phytomedicine. 55, 310-319. doi:10.1016/j.phymed.2018.10.013

Liang, T., Xu, X., Ye, D., Chen, W., Gao, B., and Huang, Y. (2019). Caspase/AIF/ Apoptosis Pathway: a New Target of Puerarin for Diabetes Mellitus Therapy. Mol. Biol. Rep. 46 (1), 4787-4797. doi:10.1007/s11033-019-04925-1

Ling, Z., Li, P., and Gao, J. H. (2011). Effects of Puerarin on Myocardial Cell Apoptosis and Related Protein Expression in Diabetic Rats. Chin. J. Basic Med. Traditional Chin. Med. 17 (3), 323-325.

Liu, J. F., Zhang, Y., and Tang, X. L. (2018). Effects of Puerarin on Glycosylated Modified Proteins in Retina of Diabetic Rats. Chin. J. Clin. Pharmacol. 34 (18), 2195-2198. doi:10.13699/j.cnki.1001-6821.2018.18.018

Liu, J., Zhang, H., Ji, B., Cai, S., Wang, R., Zhou, F., et al. (2014). A Diet Formula of Puerariae Radix, Lycium Barbarum, Crataegus Pinnatifida, and Polygonati Rhizoma Alleviates Insulin Resistance and Hepatic Steatosis in CD-1 Mice and HepG2 Cells. Food Funct. 5 (5), 1038-1049. doi:10.1039/c3fo60524h

Liu, M., Liao, K., Yu, C., Li, X., Liu, S., and Yang, S. (2014). Puerarin Alleviates Neuropathic Pain by Inhibiting Neuroinflammation in Spinal Cord. Mediators Inflamm. 2014, 1-9. doi:10.1155/2014/485927

Liu, X., Mo, Y., Gong, J., Li, Z., Peng, H., Chen, J., et al. (2016). Puerarin Ameliorates Cognitive Deficits in Streptozotocin-Induced Diabetic Rats. Metab. Brain Dis. 31 (2), 417-423. doi:10.1007/s11011-015-9779-5

Liu, Y., Qiu, Y., Chen, Q., Han, X., Cai, M., and Hao, L. (2021). Puerarin Suppresses the Hepatic Gluconeogenesis via Activation of PI3K/Akt Signaling Pathway in Diabetic Rats and HepG2 Cells. Biomed. Pharmacother. 137, 111325. doi:10.1016/J.BIOPHA.2021.111325

Meng, X. Y., Guo, S. M., and Yang, L. X. (2017). Effect of Traditional Chinese Medicine Polysaccharides in Resisting Type 2 Diabetes Insulin. Chin. J. Exp. Traditional Med. Formulae. 23 (08), 220-225. doi:10.13422/ j.cnki.syfjx.2017080220

Nanditha, A., Ma, R. C., Ramachandran, A., Snehalatha, C., Chan, J. C., Chia, K. S., et al. (2016). Diabetes in Asia and the pacific: Implications for the Global Epidemic. Diabetes Care. 39 (03), 472-485. doi:10.2337/dc15-1536

Niu, J., Xu, G., Jiang, S., Li, H., and Yuan, G. (2017). In Vitro Antioxidant Activities and Anti-Diabetic Effect of a Polysaccharide From Schisandra Sphenanthera in Rats With Type 2 Diabetes. Int. J. Biol. Macromol. 94, 154-160. doi:10.1016/ j.ijbiomac.2016.10.015

Pan, X., Wang, J., Pu, Y., Yao, J., and Wang, H. (2015). Effect of Puerarin on Expression of ICAM- 1 and TNF- $\alpha$ in Kidneys of Diabetic Rats. Med. Sci. Monit. 21, 2134-2140. doi:10.12659/MSM.893714

Prasain, J. K., Jones, K., Kirk, M., Wilson, L., Smith-Johnson, M., Weaver, C., et al. (2003). Profiling and Quantification of Isoflavonoids in Kudzu Dietary Supplements by High-Performance Liquid Chromatography and Electrospray Ionization Tandem Mass Spectrometry. J. Agric. Food Chem. 51 (15), 4213-4218. doi:10.1021/jf030174a

She, S., Liu, W., Li, T., and Hong, Y. (2014). Effects of Puerarin in STZ-Induced Diabetic Rats by Oxidative Stress and the TGF- $\beta 1 /$ Smad2 Pathway. Food Funct. 5 (5), 944-950. doi:10.1039/c3fo60565e

Shen, J. G., Yao, M. F., Chen, X. C., Feng, Y. F., Ye, Y. H., and Tong, Z. H. (2009). Effects of Puerarin on Receptor for Advanced Glycation End Products in Nephridial Tissue of Streptozotocin-Induced Diabetic Rats. Mol. Biol. Rep. 36 (8), 2229-2233. doi:10.1007/s11033-008-9438-6

Shen, Y., Yang, S., Hu, X., Zhang, M., Ma, X., Wang, Z., et al. (2019). Natural Product Puerarin Activates Akt and Ameliorates Glucose and Lipid Metabolism Dysfunction in Hepatic Cells. J. Funct. Foods. 55, 296-304. doi:10.1016/ j.jff.2019.02.035
Song, C. Y., and Bi, H. M. (2004). Effects of Puerarin on Plasma Membrane GLUT4 Content in Skeletal Muscle From Insulin-Resistant Sprague-Dawley Rats Under Insulin Stimulation. Zhongguo Zhong Yao Za Zhi. 29 (2), 172-175.

Srivali, N., Thongprayoon, C., Cheungpasitporn, W., and Ungprasert, P. (2015). Acute Pancreatitis in the Use of Canagliflozin: a Rare Side-Effect of the Novel Therapy for Type 2 Diabetes Mellitus. J. Basic Clin. Pharm. 6 (3), 101-102. doi:10.4103/0976-0105.160753

Sun, R., Deng, X., Zhang, D., Xie, F., Wang, D., Wang, J., et al. (2019). Anti-diabetic Potential of Pueraria Lobata Root Extract Through Promoting Insulin Signaling by PTP1B Inhibition. Bioorg. Chem. 87, 12-15. doi:10.1016/ j.bioorg.2019.02.046

Sun, W., Zheng, X. Z., and Li, L. (2011). Effects of Puerarin on Pancreatic Mitochondria Oxidative Stress and ATPase in Diabetic Rats. Chin. J. Clin. Rational Drug Use. 24 (4), 19-20. doi:10.15887/j.cnki.13-1389/r.2011.32.008

Tomita, T. (2016). Apoptosis in Pancreatic $\beta$-islet Cells in Type 2 Diabetes. Bosn J. Basic Med. Sci. 16 (3), 162-179. doi:10.17305/bjbms.2016.919

Wang, C., Yao, J., Ju, L., Wen, X., and Shu, L. (2020). Puerarin Ameliorates Hyperglycemia in HFD Diabetic Mice by Promoting $\beta$-Cell Neogenesis via GLP-1R Signaling Activation. Phytomedicine. 70, 153222. doi:10.1016/ j.phymed.2020.153222

Wang, T., Zhang, X. Q., Chen, A. L., Zhang, J., Lv, B. H., Ma, M. H., et al. (2020). A Comparative Study of Microbial Community and Functions of Type 2 Diabetes Mellitus Patients With Obesity and Healthy People. Appl. Microbiol. Biotechnol. 104 (12), 7143-7153. doi:10.1007/s00253-020-10689-7

Wei, L., Zhu, P., Chen, X., Wang, Y., and Xu, Y. (2020). An Ultra High Performance Liquid Chromatography With Tandem Mass Spectrometry Method for Simultaneous Determination of Thirteen Components Extracted from Radix Puerariae in Rat Plasma and Tissues: Application to Pharmacokinetic and Tissue Distribution Study. J. Sep. Sci. 43 (02), 418-437. doi:10.1002/ jssc. 201900824

Wong, K. H., Li, G. Q., Li, K. M., Razmovski-Naumovski, V., and Chan, K. (2011). Kudzu Root: Traditional Uses and Potential Medicinal Benefits in Diabetes and Cardiovascular Diseases. J. Ethnopharmacol. 134 (3), 584-607. doi:10.1016/ j.jep.2011.02.001

Wong, K. H., Razmovski-Naumovski, V., Li, K. M., Li, G. Q., and Chan, K. (2015). Comparing Morphological, Chemical and Anti-Diabetic Characteristics of Puerariae Lobatae Radix and Puerariae Thomsonii Radix. J. Ethnopharmacol. 164, 53-63. doi:10.1016/j.jep.2014.12.050

Wu, K., Liang, T., Duan, X., Xu, L., Zhang, K., and Li, R. (2013). Anti-Diabetic Effects of Puerarin, Isolated From Pueraria Lobata (Willd.), on StreptozotocinDiabetogenic Mice Through Promoting Insulin Expression and Ameliorating Metabolic Function. Food Chem. Toxicol. 60 (10), 341-347. doi:10.1016/ j.fct.2013.07.077

Xiong, F. L., Sun, X. H., Gan, L., Yang, X. L., and Xu, H. B. (2006). Puerarin Protects Rat Pancreatic Islets From Damage by Hydrogen Peroxide. Eur. J. Pharmacol. 529 (1-3), 1-7. doi:10.1016/j.ejphar.2005.10.024

Xu, M. E., Xiao, S. Z., Sun, Y. H., Zheng, X. X., Ou-Yang, Y., and Guan, C. (2005). The Study of Anti-Metabolic Syndrome Effect of Puerarin In Vitro. Life Sci. 77 (25), 3183-3196. doi:10.1016/j.lfs.2005.03.036

Xu, X., Chen, B., Huang, Q., Wu, Y., and Liang, T. (2020). The Effects of Puerarin on Autophagy Through Regulating of the PERK/eIF2a/ATF4 Signaling Pathway Influences Renal Function in Diabetic Nephropathy. Diabetes Metab. Syndr. Obes. 13, 2583-2592. doi:10.2147/DMSO.S256457

$\mathrm{Xu}, \mathrm{Y}$., Xiong, Y., Xu, C., and Xu, C. (2020). Standard Puerarin Prevents Diabetic Renal Damage by Inhibiting miRNA-140-5p Expression. Diabetes Metab. Syndr. Obes. 13, 3947-3958. doi:10.2147/DMSO.S273952

Xu, X., Zheng, N., Chen, Z., Huang, W., Liang, T., and Kuang, H. (2016). Puerarin, Isolated from Pueraria Lobata (Willd.), Protects Against Diabetic Nephropathy by Attenuating Oxidative Stress. Gene. 591 (2), 411-416. doi:10.1016/ j.gene.2016.06.032

Xue, B., Wang, L., Zhang, Z., Wang, R., Xia, X. X., Han, P. P., et al. (2017). Puerarin May Protect Against Schwann Cell Damage Induced by Glucose Fluctuation. J. Nat. Med. 71 (3), 472-481. doi:10.1007/s11418-016-1067-0

Yan, Z., Ley, S. H., and Hu, F. B. (2018). Global Aetiology and Epidemiology of Type 2 Diabetes Mellitus and its Complications. Nat. Rev. Endocrinol. 14 (02), 88-98. doi:10.1038/nrendo.2017.151 
Yang, L., Yao, D., Yang, H., Wei, Y., Peng, Y., Ding, Y., et al. (2016a). Puerarin Protects Pancreatic $\beta$-Cells in Obese Diabetic Mice via Activation of GLP-1R Signaling. Mol. Endocrinol. 30 (3), 361-371. doi:10.1210/me.2015-1213

Yang, L., Chang, X. Y., and Shi, B. (2016b). The Influence of Puerarin on the Expression of IGF-1 and TNF- $\alpha$ in Retina in Diabetic Rats. Chin. J. Lab. Diagn. 20 (5), 697-699.

Yang, W. N., Jin, H., and Feng, G. F. (2015). Puerarin Attenuates Learning and Memory Impairments and Inhibits Oxidative Stress in STZ-Induced SAD Mice. Neurotoxicology. 51, 166-171. doi:10.1016/j.neuro.2015.10.010

Ye, Y. H., Shen, J. G., Feng, Y. F., and Chen, X. C. (2013). Effect of Puerarin on Receptor of the Advanced Glycation End Products in Myocardium of Diabetic Rats. Chin. J. Mod. Drug Appl. 7 (18), 1-3. doi:10.14164/j.cnki.cn11-5581/ r.2013.18.032

Yi, Y. E., Nie, Y. N., and Yu, L. S. (2013). Effect of Puerarin Injection on EpithelialMesenchymal Transition in Renal Tubular Epithelial Cells of Diabetic KKAy Mice. Chin. J. Pathophysiology. 29 (12), 2263-2267.

Zan, L. X. (2010). Kudzu Root's Pharmacology and Comprehensive Development. Asia-pac Tradit Med. 06 (12), 161-164.

Zhang, D., and Li, M. (2019). Puerarin Prevents Cataract Development and Progression in Diabetic Rats Through Nrf2/HO-1 Signaling. Mol. Med. Rep. 20 (2), 1017-1024. doi:10.3892/mmr.2019.10320

Zhang, M., Jiang, C. M., Sun, Z., and Gong, L. F. (2009). Inhibition Effect of Puerarin on the Formation of Advanced Glycosylation End Products in Peritoneal Dialysis Solution In Vitro. J. Southeast University(Medical Sci. Edition). 28 (5), 424-426.

Zhang, Q. M., and Wang, H. (2019). Inhibitory Effect of Puerarin on Retinopathy of Diabetic Rats by Regulating Activation of Nrf2/ERK Signaling Pathway. Recent Adv. Ophthalmol. 39 (1), 22-26. doi:10.13389/j.cnki.rao.2019.0005

Zhang, S. P., Fang, W. J., Lü, J. H., Tan, H. R., and Pan, J. Q. (2006). The Experimental Study of Radix Puerariae Inhibiting Glycation in Rats Induced by D-Galactose. Zhong Yao Cai. 29 (3), 266-269. doi:10.13863/j.issn1001-4454.2006.03.023

Zhang, Y., Wang, H., Yu, L., and Chen, J. (2015). The Puerarin Improves Renal Function in STZ-Induced Diabetic Rats by Attenuating eNOS Expression. Ren. Fail. 37 (4), 699-703. doi:10.3109/0886022X.2015.1011500

Zhao, Q. Q., Xiang, L. I., and Zeng, M. L. (2015). A Network Pharmacology Based Study of Regulation Effects of the Main Active Components in Honghua
Injection on Cerebrovascular Disease Network. Chin. Pharm. J. 50 (16), 1402-1407. doi:10.3109/0886022x.2015.1011500

Zhao, Y., and Zhou, Y. (2012). Puerarin Improve Insulin Resistance of Adipocyte Through Activating Cb1 Binding Protein Path. Chin. J. Integr. Med. 18 (4), 293-298. doi:10.1007/s11655-012-1058-2

Zhao, Y. H., Chi, L. X., Lei, T., and Chen, Y. M. (2008). The Study of Angiotensin-II Inducing Apoptosis in Neonatal Rat Cardiomyocytes. Mol. Cardiol. China. 2008 (02), 83-86. doi:10.16563/j.cnki.1671-6272.2008.02.008

Zhi, D., Sui, D., and Rui, Q. I. (2018). Potential Targets of Pueraria in Treatment of Hyperlipoproteinemia Based on Network Pharmacology. J. Jilin University(Medicine Edition). 44 (04), 724-730+891. doi:10.13481/j.1671587x.20180406

Zhou, Y. X., Zhang, H., and Peng, C. (2014). Puerarin: A Review of Pharmacological Effects. Phytother Res. 28 (07), 961-975. doi:10.1002/ptr.5083

Zhu, L. H., Wang, L., Wang, D., Jiang, H., Tang, Q. Z., Yan, L., et al. (2010). Puerarin Attenuates High-Glucose-And Diabetes-Induced Vascular Smooth Muscle Cell Proliferation by Blocking PKCbeta2/Racl-Dependent Signaling. Free Radic. Biol. Med. 48 (4), 471-482. doi:10.1016/j.freeradbiomed.2009.10.040

Conflict of Interest: The authors declare that the research was conducted in the absence of any commercial or financial relationships that could be construed as a potential conflict of interest.

Publisher's Note: All claims expressed in this article are solely those of the authors and do not necessarily represent those of their affiliated organizations, or those of the publisher, the editors and the reviewers. Any product that may be evaluated in this article, or claim that may be made by its manufacturer, is not guaranteed or endorsed by the publisher.

Copyright (C) 2022 Bai, Han, Qian and Wang. This is an open-access article distributed under the terms of the Creative Commons Attribution License (CC $B Y)$. The use, distribution or reproduction in other forums is permitted, provided the original author(s) and the copyright owner(s) are credited and that the original publication in this journal is cited, in accordance with accepted academic practice. No use, distribution or reproduction is permitted which does not comply with these terms. 


\section{GLOSSARY}

1-A 1-Adrenaline

a1-AR a1-Adrenergic Receptors

a-SMA Alpha-Smooth Muscle Actin

a1A-AR a1A-Adrenergic Receptors

$\boldsymbol{\beta}$-EP $\beta$-Endorphin

Bax Bcl-2-Associated X

Bcl-2 $\beta$-cell lymphoma-2

ACC Acetyl Carboxylase

AGEs Advanced Glycation End Products

Akt/PKB Protein Kinase B

Akt1 Protein Kinase Ba2

AMPK AMP-Activated Protein Kinase

Ang-II Angiotensin II

ATF4 Activating Transcription Factor 4

Atg5 Autophagy-Related 5 Homolog

CAT Catalase

CD36/FAT Fatty Acid Translocase

CGRP Calcitonin Gene-Related Peptide

CPT-1b Carnitine Palmitoyltransferase- $1 \mathrm{~b}$

Cyt-C Cytochrome C

DM Diabetes MellitusDiabetic Macroangiopathy

DPN Diabetic Peripheral Neuropathy

DN Diabetic Nephropathy

DM Diabetes MellitusDiabetic Macroangiopathy

DR Diabetic Retinopathy

DC Diabetic Cardiomyopathy

eIF2 $\boldsymbol{\alpha}$ Eukaryotic Translation Initiation Factor $2 a$

ECM Extracellular Matrix

eNOS Endothelial Nitric Oxide Synthase

ET-1 Endothelin-1

FBG Fasting Blood Glucose

Foxo1 Forkhead Box Transcription Factor O1

GLP-1R Glucagon-like Peptide-1 Receptor

GLUT4 Glucose Transporter 4

GSK-3 $\beta$ Glycogen Synthase Kinase-3 $\beta$

G6pase Glucose-6-Phosphatase

HbA1c Glycated Hemoglobin

HMGB1 High Mobility Group Box 1

ICAM-1 Intercellular Cell Adhesion Molecule-1

IDF International Diabetes Federation

IGF-1 Insulin-like Growth Factor-1

IL-6 Interleukin- 6
IL-1 $\beta$ Interleukin-1 $\beta$

INF- $\boldsymbol{\gamma}$ Interferon- $\gamma$

IMCLs Intramyocellular Lipids

iNOS Inducible Nitric Oxide Synthase

InsR Insulin Receptor

IRS-1 Insulin Receptor Substrate-1

IR Insulin Resistance

LC3II Microtubule-Associated Protein Light Chain 3 II

LKB1 Liver Kinase B1

LOX-1 Lectin-like Oxidized Low-Density Lipoprotein Receptor-1

MAPK Mitogen-Activated Protein Kinases

MDA Malondialdehyde

NF-kBp65 Nuclear Factor-kBp65

NF-кB Nuclear Factor Kappa-Light-Chain-Enhancer of Activated $\beta$-Cells

NO Nitric Oxide

NOX NADPH Oxidase

NOX4 NADPH Oxidase 4

NOX2 NADPH Oxidase 2

Nrf2 Nuclear Factor-E2 Related Factor2

PARP Poly ADP-Ribose polymerase

PDX-1 Pancreatic Duodenum Homeobox-1

PDE3 Phosphodiesterase 3

PEPCK Phosphoenolpyruvate Carboxykinase

p-ERK Activated Extracellular Signal-Regulated Kinase

PGC-1 $\alpha$ Peroxisome Proliferator Activated Receptor $\gamma$ coactivator-1 $\alpha$

PI3K Phosphatidylinositol 3 Kinase

PLC-PKC Phospholipase C-Protein kinase C

PPARa Peroxisome Proliferators-activated Receptors a

PPAR $\gamma$ Peroxisome Proliferators-activated Receptors $\gamma$

PKB Protein Kinase B

PTP-1B Protein Tyrosine Phosphatase-1B

RAS Renin-Angiotensin System

ROS Reactive Oxygen Species

RP Radix Puerariae

RXR Retinoic Acid Receptor

RPE Retinal Pigment Epithelial Cells

SCs Schwann Cells

SIRT1 Sirtuins1

SIRT3 Sirtuins 3

SOD Superoxide Dismutase

SOD2 Superoxide Dismutase 2

TCM Traditional Chinese Medicine

TGF- $\beta 1$ Transforming Growth Factor- $\beta 1$ 
TGF- $\beta$-RI Transforming Growth Factor $\beta$ I Receptors

TNF- $\boldsymbol{\alpha}$ Tumor Necrosis Factor- $\boldsymbol{\alpha}$

TXNIP Thioredoxin-Interacting Protein
UCP2 Uncoupling Protein 2

VSMCs Vascular Smooth Muscle cells

VEGF Vascular Endothelial Growth Factor 